\title{
31. SILICA DIAGENESIS IN CONTINENTAL MARGIN SEDIMENTS OFF NORTHWEST AFRICA
}

\author{
Ulrich von Rad, Volkher Riech, and Heinrich Rösch, Bundesanstalt für Geowissenschaften und Rohstoffe \\ (Federal Geological Survey), D 3000 Hannover 51, West Germany
}

\begin{abstract}
Investigations using optical, scanning, and transmission electron microscopy, and X-ray diffraction of 79 samples of silicified Oxfordian to early Miocene sediments off northwest Africa yielded the following major results:

1) Only opal-CT porcellanites are present in post-middle Eocene marls and in Late Cretaceous to Eocene claystones; only quartz cherts were found in Oxfordian to Early Cretaceous limestones.

2) Opal-CT (a) precipitated from solution during intermediate diagenesis after formation of a first calcite cement and before any matrix quartz is formed; and (b) was formed by in situ replacement of radiolarian skeletons.

3) Silicification proceeds in the carbonate environment from isolated lepispheres in pores to one or more centrifugally progressing (opal-CT) silicification fronts which are later replaced by quartz from a core outwards.

4) Opal-CT and authigenic palygorskite/sepiolite in clayey sediments produce an "aggregate polarization" presumably caused by oriented growth parallel to the bedding plane.

5) The maturation of the opal-CT structure is suggested by the progressive shift of the $d(4.1 \AA)$ spacing with burial depth (temperature, ?time.

6) The ultrastructure of lepisphere characteristic interpenetration of opal-CT blade is governed by tridymite twinning laws.

7) Quartz is directly precipitated only in foraminiferal tests and pores within the nodules.

8) Indicated by porcellanite relicts, quartz-replaced lepispheres, etc., all typical quartz cherts were developed by gradual maturation from porcellanites, not by direct precipitation without an opal-CT precursor.

9) The rate of opal-CT $\rightarrow$ quartz transformation is much slower in the clayey sediments (?30-60 m.y.) than in a carbonate environment (5-20 m.y.).
\end{abstract}

\section{INTRODUCTION}

Detailed studies of siliceous ooze and silicified rocks from DSDP sediments have yielded many new insights into silica diagenesis and the origin and formation of porcellanites and cherts (Calvert, 1971; 1974; Heath and Moberly, 1971; Wise et al., 1972; Wise and Weaver, 1973; 1974; von Rad and Rösch, 1972, 1974; Lancelot, 1973; Keene, 1975). Great progress has been made during the past 5 years in the identification of various silica modifications, in the application of the DSDP results to Cretaceous and Tertiary silicified shallowwater sediments on land (e.g., Wise and Weaver, 1973; Hakansson et al., 1974; Aubry, 1975; Murata and Larson, 1975), and in testing of hypothetical diagenetic processes by hydrothermal experiments (e.g., Oehler, 1973; Kastner and Keene, 1975; Flörke et al., 1975). There are, however, still major controversies about the sources of free silica, and the major factors and processes influencing the transformation of precursor sediments into bedded or nodular porcellanites and into quartz cherts.
Seventy-nine samples from Leg 41 were studied, ranging in age from early Miocene to Oxfordian. These include a spectrum from weakly silicified chalks to mature quartz cherts, from abyssal sediments deposited below the CCD to a relatively shallow slope setting, and from eupelagic, oceanic to hemipelagic facies with a strong terrigenous influx. Most of the drill sites are located in a continental margin area with strong coastal upwelling (Canary Current). This resulted in high productivity of calcareous and siliceous plankton which is reflected by relatively high accumulation rates and good preservation of opaline silica in the surface sediments (Berger and von Rad, 1972). Thus, these sediments are ideal for a study of that portion of the silica cycle which is permanently preserved in the fossil record by diagenetic transformation of amorphous silica into crystalline varieties.

Investigations of the different stages of silica diagenesis should also contribute to the interpretation of acoustic reflectors, such as the widespread Eocene Horizon "A," often found to be porcellanite or chert. Correlations of these reflectors are an important 
prerequisite for the structural and paleoenvironmental interpretation of thick upper continental rise/lower continental slope sequences which may be promising hydrocarbon reservoirs of the future.

A detailed study of the mineralogy, micro- and "nannofacies" of our samples was performed by semiquantitative X-ray diffraction (XRD), optical, and scanning (or transmission) electron microscope (SEM/TEM) analyses in order to investigate (1) the petrographic and mineralogical composition and ultrastructure of silicified sediments, and (2) the nature and sequence of mineral transformations (dissolution, recrystallization, authigenesis, replacement) during diagenetic evolution.

Preliminary results of our studies are summarized in this paper. Some of our new discoveries will be studied in greater detail and published elsewhere.

\section{METHODS OF INVESTIGATION}

Qualitative and semiquantitative thin-section analyses were made on all samples. Special subsamples were selected for further XRD, SEM, and TEM studies.

It was possible to isolate the different silica polymorphs for more detailed studies by selective dissolution with various acids:

Carbonate-rich sediments were dissolved in $\mathrm{HCl}$ to concentrate $\mathrm{SiO}_{2}$ modifications or to dissolve relict carbonate in porcellanites (Plate 3, Figures 1-4; Plate 4, Figures 1-3).

Structureless surfaces of chert and porcellanite were treated for 1 to $20 \mathrm{~min}$ with $\mathrm{HF}$ or $\mathrm{H}_{2} \mathrm{SiF}_{6}$, to produce a higher microrelief or to resolve sedimentary, biogenous, or diagenetic microstructures. Biogenous opal-A is more easily dissolved in $\mathrm{H}_{2} \mathrm{SiF}_{6}$ than is opalCT, but opal-CT is more easily dissolved than is quartz (Chapman et al., 1969; Henderson et al., 1972). In this way quartz-replaced "lepispheres" or microfossils can be isolated from porcellanites (after up to 3 days of treatment). The optical properties of the insoluble particles were determined under the polarizing microscope, before scanning electron microscopy was attempted (Plate 3, Figures 1-3; Plate 4).

Fresh fractures of Au-coated specimens or acidisolated components were scanned with a Siemens (ETEC) Autoscan scanning electron microscope at 20-30 kV (operator E. Knickrehm, Hannover).

The elemental composition of selected silica phases and silicates was determined by energy-dispersive X-ray analysis (EDAX, kindly provided by Dr. Hantsche, BAM, Berlin). These determinations are useful to distinguish $\mathrm{SiO}_{2}$ and carbonate within the dense matrix, variations of $\mathrm{Mg}$ content in carbonates, and the composition of undetermined fibrous silicates.

The analytical procedures for $X$-ray diffractometry follows the method described in von Rad and Rösch $(1972,1974)$. The semiquantitative percentages of Table 2 were measured with a standard deviation of less than $10 \%$ using mainly the "method of transparent specimens." But, because of the mineralogical errors, mainly the choice of appropriate standards, the percentages may considerably exceed this accuracy.

A multiple preparation/diffraction technique was applied with both a Philips Norelco diffractometer
(CuKa $a_{1}$ + graphite monochromator) and a high resolution Guinier diffractometer $\left(\mathrm{CuK} a_{1}\right.$, bent quartz monochromator) in order to get precise $d$ measurements of the opal-CT $4.1 \AA$ spacing. The main analytical problem is the accurate measurement of the position of the relatively broad opal-CT peak.

Transmission electron microscope (TEM) and electron diffraction analysis was applied in order to determine the mineralogy and the lattice parameters of the particles comprising the opal-CT lepispheres.

\section{CLASSIFICATION OF SILICIFIED SEDIMENTS}

The classification proposed in this paper (Table 1) is based mainly on the semiquantitative estimate of the proportion of the $\mathrm{SiO}_{2}$ polymorphs present in silicified sediments: opal-A, opal-CT, diagenetic (microcrystalline or chalcedonic) quartz (nomenclature of opal after Jones and Segnit, 1971). Also the content of fossils (diatoms, radiolarians, foraminifera, nannofossils) and of authigenic silicates (zeolites, palygorskite, sepiolite) is considered. It is essential for this nomenclature that the amounts of these three silica phases are estimated by thin-section and XRD analyses for each specimen.

In addition to the purely descriptive approach, our nomenclature includes some widely accepted qualita-

TABLE 1

Classification of Silicified Sediments (the Same Symbols are Used in Figures 1, 4, and 7)

A. "IMMATURE," WEAKLY SILICIFIED ("PRECURSOR") SEDIMENTS

$<50 \%$ diagenetic $\mathrm{SiO}_{2}$, mostly opal-CT $>$ quartz

diag. qtz: mostly $<15 \%$ (w/o opal-CT precursor; replacing calcareous fossils or precipitated in pores)

opal-CT: $<35 \%$ (impregnation, replacement, pore filling)

opal-A: various admixtures of skeletal opal-A

AI "bedded" types in clayey facies: auth. silicates (palygorskite, sepiolite, zeolites) + diagenetic carbonates (calcite, dolomite)

"mass polarization" due to oriented growth of palygorskite/ sepiolite/opal-CT?

AII "nodular" types in calcareous facies

A/B-transitions: $35 \%$ - $~ 50 \%$ opal-CT

B. PORCELLANITES: $>50 \% \mathrm{SiO}_{2}$, opal-CT > diagenetic quartz diagen. qtz.: mostly $5 \%-15 \%$ as in A opal-CT: $\quad 50 \%-95 \%$

opal-A: usually dissolved and/or replaced by opal-CT or qtz.

BI bedded porcellanites in clayey facies

1) hemipelagic, diatom-rich (diatoms $>$ rads, terrigenous min.: $0-10 \%$ carbonate, $-5 \%$ palyg., indistinct mass polar.)

2) pelagic, radiolarian-rich (rads $>$ diatoms, $-15 \%$ zeolites, $<10 \%$ palyg./sepiolite, indistinct mass polar.)

3) ? hemipelagic, palygorskite-rich (5-60\% palyg./ sepiolite, strong aggr polar., terrigen. $\mathrm{min} .,-15 \%$ carbonates, $-10 \%$ zeolites)

BII nodular porcellanites ("embryo flints") in calcareous facies

BIII opal-CT cemented clastic rocks (conglomerates etc.)

B/C transitions: mostly $15 \%-50 \%$ q tz

zoned porcellanite nodules with core of qtz chert

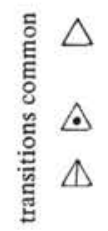

C. "MATURE" QUARTZ CHERTS: $>50 \%$ diag. $\mathrm{SiO}_{2}$, qtz $>$ opal-CT

$\mathrm{CI}$ bedded quartz cherts in clayey facies (= aged porcellanites BI 1-3)

CII nodular quartz cherts in calcareous facies (=flints) a) aged porcellanites B II

b) ? directly precipitated cherts (unlikely in Leg 41 sediments)

$\left.\begin{array}{ll}\mathrm{CI} & \text { (BI) } \\ \mathrm{CII} & \text { (BII) }\end{array}\right\}$ quartz cherts with porcellanitic relicts

CIII quartz cemented clastic rocks 
tive and genetic terms. For example, we differentiate between "bedded" varieties in "clayey" environments, and "nodular" types (or flints) characteristic of calcareous environments. Our genetic interpretation for the different silica transformations from siliceous oozes via weakly silicified sediments and porcellanites to mature quartz cherts is given in Figure 6.

\section{DISTRIBUTION OF SILICIFIED SEDIMENTS}

Opal-CT is present in rocks from Leg 41 ranging in age from 20 m.y. (early Miocene, Site 370 ) to 72 m.y. (Campanian, Site 369), and possibly Late Cretaceous at Sites 367 and 368 (Figure 1). The ages of quartz cherts range from 155 m.y. (Oxfordian to Kimmeridgian, Site 367 ) to 47 m.y. (middle Eocene, Sites 366 and 370). The youngest quartz cherts at Sites 367 and 368) occur at an older level (older than Campanian?) than at Sites 366 and 370 (middle Eocene). Only porcellanites were found in the samples from Sites 368 and 369.

Nodular porcellanites and quartz cherts (including all transitional stages) are frequent in calcareous and marly host rocks of Site 366 (Paleocene to Eocene) and Site 367 (Oxfordian to Early Cretaceous). They also occur, however, in nanno-bearing calcareous claystones of Site 370 (Eocene to Miocene).

Clayey, palygorskite/sepiolite-rich, bedded porcellanites are frequent in clayey host rocks from Site 367 (Late Cretaceous to Eocene), Site 370 (Eocene to Miocene), and especially Site 368 (Late Cretaceous to Eocene).

\section{MICRO- AND NANNOFACIES OF SILICIFIED SEDIMENTS}

\section{Clayey Environment ("bedded porcellanites")}

"Bedded" porcellanites, derived from clays and claystones with various amounts of terrigenous silt, nannofossils, radiolarians, or diatoms are less abundant in the Leg 41 samples than in previously studied samples from deeper and more pelagic environments (von Rad and Rösch, 1972, 1974). The palygorskite-bearing porcellanite (type $\mathrm{BI}_{3}$ ) (von Rad and Rösch, 1972, 1974) is relatively common in the greenish hemipelagic silty clays of Site 368 and in the pelagic zeolitic clays of Site 367. Transitions into the pelagic $\left(\mathrm{BI}_{2}\right)$ and hemipelagic $\left(\mathrm{BI}_{1}\right)$ types (see Table 1) do exist.

Porcellanite was the only phase observed within the carbonate-free clayey environments at all Leg 41 sites. The oldest investigated porcellanites are ?Late Cretaceous in age (Site 368). Diagenetic quartz is restricted to local pore fillings, replaced skeletons of radiolarians, diatoms, sponge spicules, or (very rarely) to quartz-replaced lepispheres; opal-CT of the clay matrix was not found transformed into quartz.

The microfacies of bedded porcellanites is shown in Figure 2 (5-8) and Plate 1 (Figures 1-6). Carbonate-free varieties (Figure 2: 5a, 6) consist of an opal$\mathrm{CT} /$ palygorskite/sepiolite matrix with pyrite, detrital quartz, as well as opal-CT, quartz-, pyrite-, or zeolitereplaced and -filled siliceous fossils (Plate 1, Figures 2 and 5). Another type contains up to $15 \%$ carbonate as nannofossils, authigenic carbonate rhombs, or both (Figure 2: 5b, 7, 8). The nannofossils show up well in thin-sections because of their paucity. They can also be studied after etching with $\mathrm{HF}$ or $\mathrm{H}_{2} \mathrm{SiF}_{6}$ under the SEM. Layers or lenses of silt-sized quartz, and sometimes microplacer deposits of pyritized radiolarians and fish debris were recognized locally (Figure 2: 6, 8).

\section{Opal-CT, Palygorskite-sepiolite, and the Phenomenon of "Aggregate Polarization"}

Usually porcellanite of group $\mathrm{BI}_{3}$ is very rich in opalCT (up to $65 \%$ ) and relatively rich in the aqueous $\mathrm{Mg}$ alumino- (chain-)silicate palygorskite (5\% to $30 \%$ ). Sepiolite, also a fibrous aqueous $\mathrm{Mg}$-silicate, is a minor admixture of palygorskite in most cases and occasionally it can reach $20 \%$ to $40 \%$.

Thin sections of silicified sediment samples of this group show a uniform extinction of the total matrix under crossed nicols, if the polarizer or analyzer are oriented parallel to the bedding plane (Plate 1, Figure 1). We call this phenomenon "aggregate polarization." It ranges from "very weak" to "strong" (Table 2). Fine laminations can locally deviate from the horizontal plane because of detrital layers or differential compaction. When this occurs, there is no complete extinction parallel to the bedding. This also explains the phenomenon of the "winged radiolarians" shown in Plate 1 (Figure 2) and Figure 2 (8).

The optical behavior of opal-CT is surprisingly different in nodular and bedded porcellanites. The opal-CT content in nodular porcellanites (carbonate environment) can be easily determined by its almost isotropic character. However, because of aggregate polarization effects, it is impossible to determine isotropic areas within the clay-rich bedded porcellanites. These chain silicates can be recognized in SEM photos of rocks with a small palygorskite/sepiolite content only as pore fillings (Figure 2: 6; Plate 1, Figures 3, 4). In some cases they are also seen as a network of thin filaments covering or bridging opal-CT lepispheres (368-33-1, 96-98 cm). They have been shown by EDAX to be a silicate rather than "amorphous silica" or "quartz whiskers," as assumed by Leclaire (1974) or Froehlich (1974).

One sample shows pores elongated parallel to the bedding plane with clearly recognizable palygorskite mats along the walls. These can be distinguished from subspherical radiolarian ghosts filled only with lepispheres and zeolites (Plate 1, Figures 4, 5). Palygorskite has been formed in all these cases as an authigenic mineral, apparently during intermediate diagenesis (see page 895 ).

The intensity of the aggregate polarization (a.p.) correlates negatively with the pigmentation of the matrix. Distinct transparent zones show maximum a.p. as well as a maximum of authigenic dolomite rhombs surrounded by a brownish rim (Figure 2: 5 b). The content of biogenic and diagenetic carbonates (nannofossils, foraminifera, dolomite) and of brownish iron oxides increases as the a.p. decreases (367-11-1).

If the palygorskite and sepiolite contents (X-ray determinations) are plotted against the intensity of a.p. (estimated in thin-sections), then the following can be 


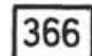

S. Leone Rise Subbottom

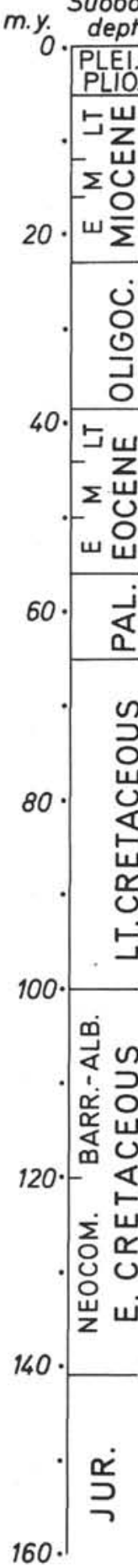

h $2860 \mathrm{~m}$

$255 \frac{1}{1 \frac{1}{1} 1}$

$-1-1-$

\begin{tabular}{|l|}
$-1-1-1$ \\
\hline$-1-1-1$ \\
\hline $1-1$
\end{tabular}

$418 \frac{1}{\frac{1}{11}}$
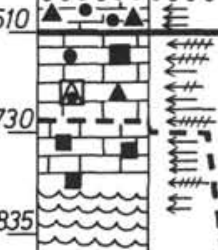

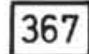

C. Verde Basin

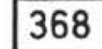

C. Verde Rise
369

Slope off

C. Bojador
370

Moroccan Basin
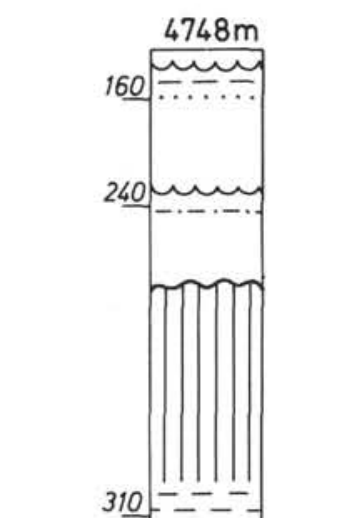

(3)

$3367 \mathrm{~m}$

$\sim 135$

ning

$+ \pm$

uㅔ

프드

inin-

$\div \div \div-\div$

310

$--$

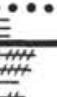

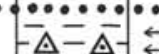

$\Delta-\Delta$

5 a 3900

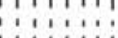

$\bar{\Delta}=\Delta \leftarrow$ a

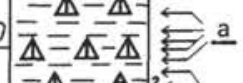

m

$4216 \mathrm{~m}$

?

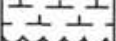

win

$\simeq \simeq$

……

165 는

는

- - -

mon

ins.

346 गागा

6

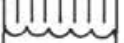

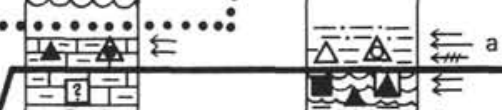
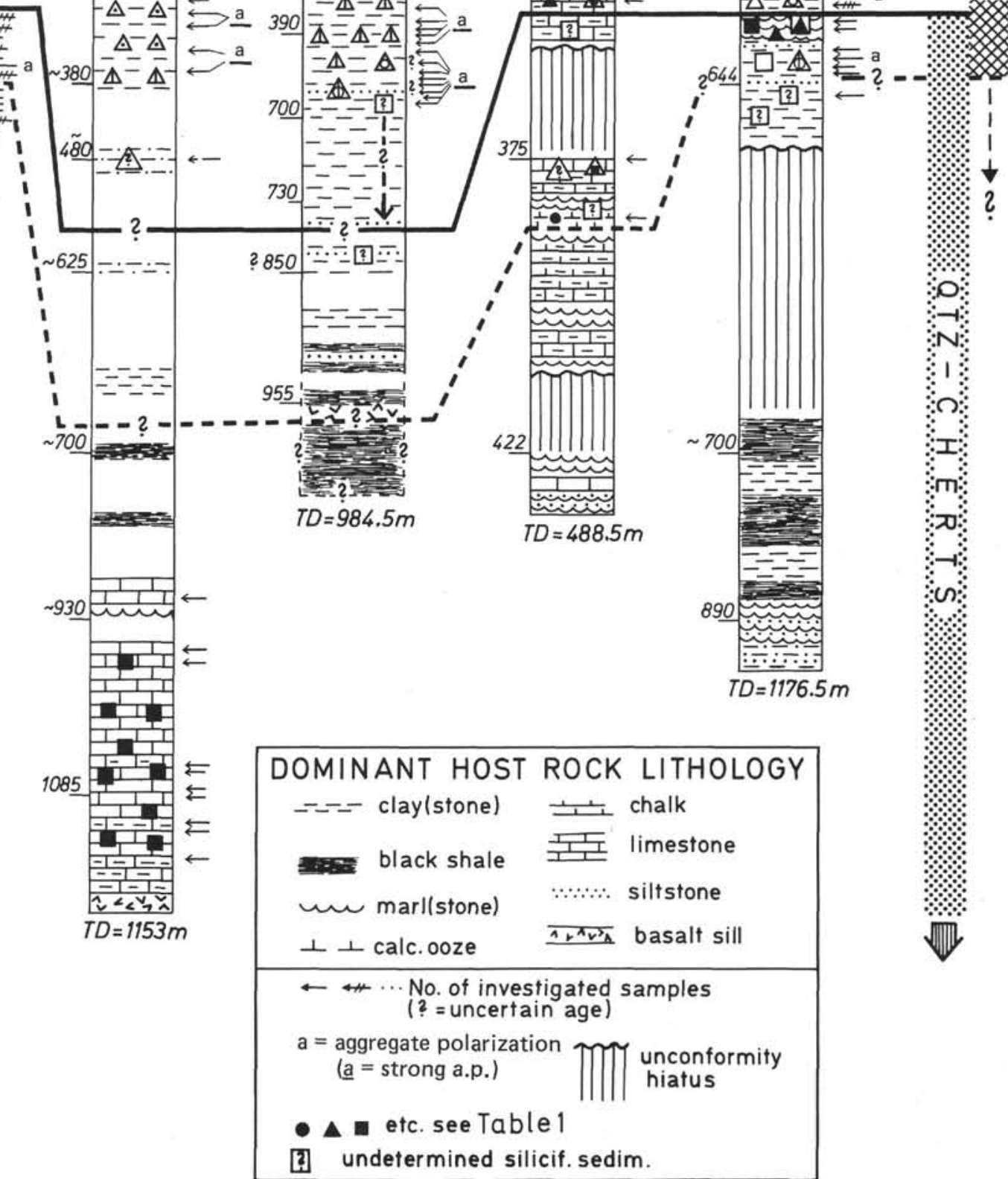

Figure 1. Lithostratigraphy and age distribution of silicified sediments at Sites 366 through 370 (for symbols see Table 1). 


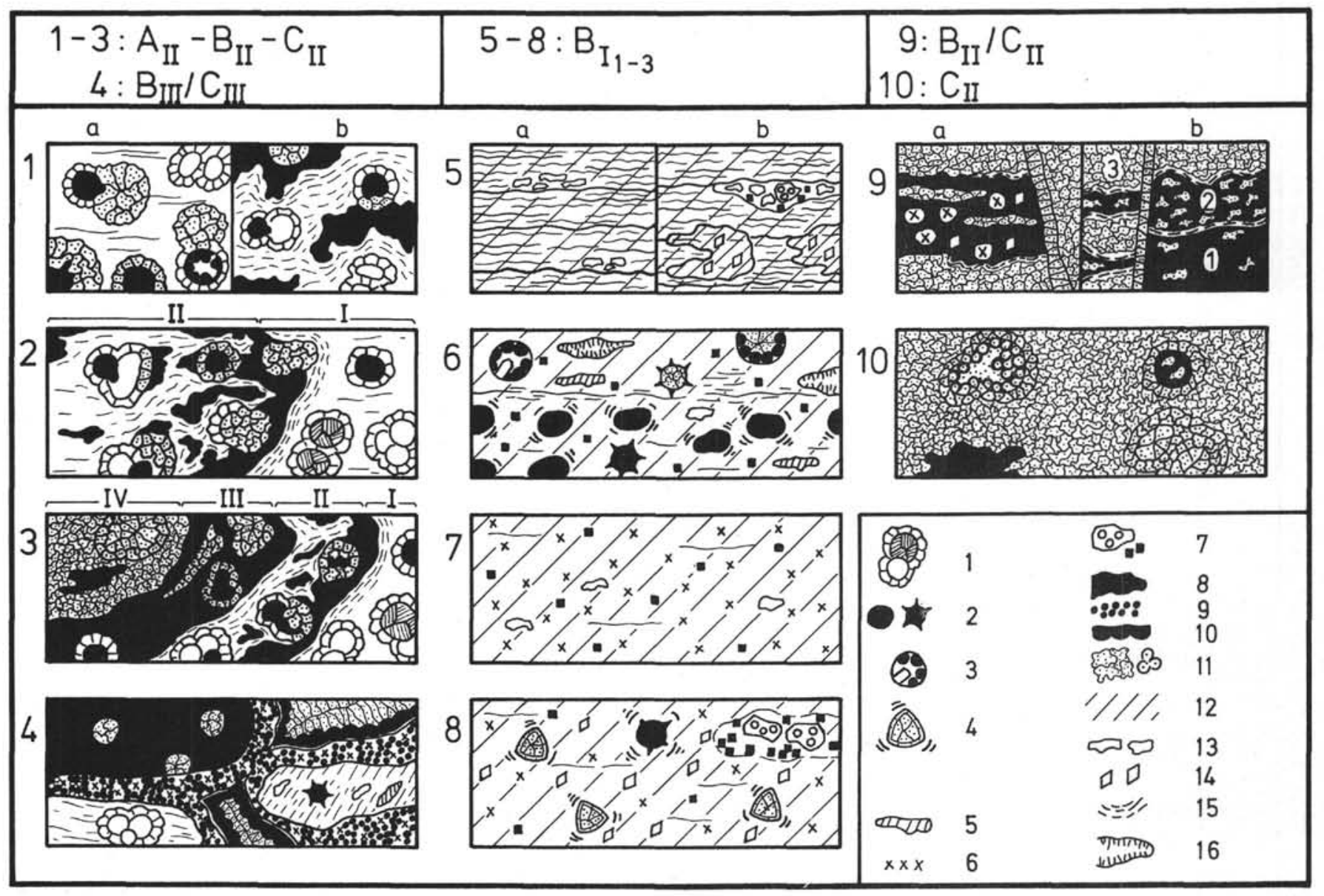

Figure 2. Microfacies of silicified Leg 41 sediments (generalized line drawings after typical thin-section or SEM photomicrographs). Facies types 1-3, 9-10 = calcareous and marly facies; 5-8= clayey facies; $4=$ silica-cemented conglomerate (Eocene, Site 370). Further explanation in text. The distribution of dense opal-CT matrix can be recognized only in calcareous sediments (it is shown black because of its \pm isotropic character). The aggregate polarization in types 5-8 makes it impossible to distinguish opal-CT in the matrix. Explanation of symbols: 1 = calcite-preserved foraminifera (with calcite cement); 2 = opal-CT-filled and-replaced radiolarians (right: with details of skeleton preserved); $3=$ radiolarian ghost with lepisphere and zeolite fillings; 4 = quartz-replaced "winged" diatoms (see Plate 1, Figure 2); 5 = fish remains; 6 = nannofossils; $7=$ pyritized radiolarian fragments and pyrite crystals; $8=$ dense opal-CT matrix; $9=$ small lepispheres in matrix; $10=$ opal-CT rim cement; 11 = diagenetic quartz, quartz-replaced lepispheres; 12 = matrix with aggregate polarization; $13=$ detrital quartz; 14 = dolomite; 15 = clay mineral concentrations; 16 = palygorskite-filled elongate pores.

seen: (a) significant a.p. values are only found in rocks containing palygorskite and/or sepiolite; (b) very high a.p. occurs in samples with $<10 \%$ palygorskite and mostly $50 \%$ to $60 \%$ opal-CT, but also in samples with $10 \%$ to $60 \%$ palygorskite/sepiolite and $<25 \%$ opal-CT.

In opal-CT-rich samples, from which fractures perpendicular and parallel to the fine laminations were scanned, no preferred orientation was noted for the minerals within the structureless matrix. However, one sample with a palygorskite + sepiolite content of $60 \%$ showed mats of fibers clearly oriented parallel to the bedding plane (Sample 368-36-3, 47-49 cm).

\section{Replacement of Siliceous Organisms}

For convenience, the sequence of mineral transformations in siliceous organisms is discussed together with that for clay (Figure 2: 6, 8; Plate 4, Figures 4,5) and carbonate environments (Plate 4, Figures 1-3).
No siliceous skeletons composed of original opal-A could be positively identified under the light or scanning electron microscope in sediments of Miocene to Jurassic age. In general, the percentages of X-ray amorphous material do not agree well with the optically determined contents of siliceous organisms. Apparently, they represent maximum contents of opalA (see page 891).

It was possible for the first time to show that radiolarian skeletons from Eocene rocks are preserved as opal-CT (Plate 4, Figures 1-3). The well-preserved skeletons are covered by subparallel or interpenetrated opal-CT blades. Coccoliths are included by the active outward growth of opal-CT. Pores within the skeletons have grown together in places. We assume that the invisible inner parts of the skeletons also consist of pure opal-CT. Diatoms and sponge spicules apparently lack an intermediate opal-CT phase because in our samples they are always replaced by quartz. 
TABLE 2

Lithofacies, Age, XRD, Thin-Section, and SEM Data of Selected Leg 41 Samples

\begin{tabular}{|c|c|c|c|c|c|c|c|c|c|c|c|c|}
\hline \multirow[b]{2}{*}{$\begin{array}{c}\text { Sample } \\
\text { (Interval in cm) }\end{array}$} & \multirow[b]{2}{*}{ Age } & \multirow{2}{*}{ 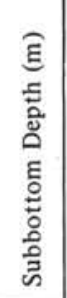 } & \multirow[b]{2}{*}{$\begin{array}{c}\text { Host Rock } \\
\text { Lithology }\end{array}$} & \multirow[b]{2}{*}{$\begin{array}{c}\text { Petrography of } \\
\text { Investigated Sample } \\
\text { (Table 1) }\end{array}$} & \multicolumn{6}{|c|}{ Mineralogical Composition } & \multirow{2}{*}{ 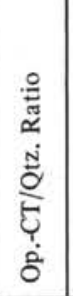 } & \multirow{2}{*}{ 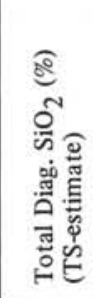 } \\
\hline & & & & & 尝: & $\frac{Y^{\frac{\pi}{\pi}}}{0}$ & 量 & $\frac{\stackrel{2}{0}}{\tilde{n}}$ & 离 & 总离 & & \\
\hline $366-17-1,5-7$ & M. Eoc. & 480 & \begin{tabular}{|lll}
1 & & \\
1 & & $\infty$ \\
& & \\
\end{tabular} & $\mathrm{A}_{\mathrm{II}} / \mathrm{B}_{\mathrm{II}}$ & 15 & 50 & 20 & 15 & - & - & 2.5 & $10-60$ \\
\hline $366-18-1,28-30$ & M. Eoc. & 499 & 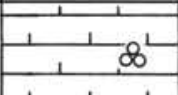 & $\mathrm{A}_{I I} / \mathrm{B}_{I I}$ & 15 & 45 & 20 & 20 & - & - & 2.3 & 12 \\
\hline $366-19-1,120-122$ & M. Eoc. & 500 & \begin{tabular}{|ll} 
& \\
& 1
\end{tabular} & $\mathrm{~A}_{I I} / \mathrm{B}_{I I}$ & 15 & 45 & 25 & 15 & - & - & 1.9 & $0-80$ \\
\hline $366-21-2,86-88$ & M. Eoc. & 520 & \begin{tabular}{|l|}
1,1 \\
$, 1, d 8$ \\
\end{tabular} & $\mathrm{~B}_{\mathrm{II}} / \mathrm{C}_{\mathrm{II}}$ & 15 & 35 & 50 & - & - & - & 0.7 & 90 \\
\hline $366-23-1,39-41$ & M. Eoc. & 537 & & $\mathrm{~A}_{I I} / \mathrm{B}_{I I}$ & $\begin{array}{r}5 \\
15\end{array}$ & $\begin{array}{l}10 \\
45\end{array}$ & $\begin{array}{r}0 \\
40\end{array}$ & $\begin{array}{l}85 \\
<5\end{array}$ & $\begin{array}{l}- \\
-\end{array}$ & $\begin{array}{ll}- \\
-\end{array}$ & $\begin{array}{l}\infty \\
1.1\end{array}$ & $1-90$ \\
\hline $366-24-3,80-82$ & M. Eoc. & 550 & 1 & $\begin{array}{ll}\mathrm{A}_{I I} / \mathrm{B}_{\mathrm{II}} \mathrm{C}_{\mathrm{II}} & \text { Itgy: } \\
\text { Figure 2: 3) } & \text { mgy: }\end{array}$ & \begin{tabular}{|l|}
15 \\
20
\end{tabular} & $\begin{array}{l}45 \\
35\end{array}$ & $\begin{array}{l}25 \\
45\end{array}$ & $\begin{array}{l}15 \\
-\end{array}$ & - & - & $\begin{array}{l}1.9 \\
0.8\end{array}$ & $2-98$ \\
\hline $366-26-2,101-104$ & M. Eoc. & 568 & \begin{tabular}{|l|l|}
1 & \\
1 \\
\end{tabular} & $\mathrm{~A}_{\mathrm{II}} / \mathrm{B}_{\mathrm{II}}$ & 15 & 45 & 25 & 15 & - & - & 0.8 & $3-80$ \\
\hline $366-27-3,14-18$ & M. Eoc. & 578 & \begin{tabular}{|l|l|l|} 
& & \\
& \\
\end{tabular} & $A_{I I}$ & 5 & 15 & 0 & 80 & - & - & $\infty$ & 5 \\
\hline $366-29-1,50-52$ & E. Eoc. & 595 & \begin{tabular}{|l|l|l|}
-1 & - \\
1 & -1 & 0 \\
\end{tabular} & \begin{tabular}{|ll}
$\mathrm{C}_{\mathrm{II}}\left(\mathrm{B}_{\mathrm{II}}\right)$ & $\begin{array}{r}\text { Itgy: } \\
\text { dgy: }\end{array}$ \\
(Plate 2, Figure 4)
\end{tabular} & $\begin{array}{l}25 \\
40\end{array}$ & $\begin{array}{r}20 \\
5\end{array}$ & $\begin{array}{l}55 \\
55\end{array}$ & $\begin{array}{l}- \\
-\end{array}$ & - & $\begin{array}{ll}- \\
-\end{array}$ & $\begin{array}{l}0.4 \\
0.1\end{array}$ & 95 \\
\hline $366-29-1,59-61$ & E. Eoc. & 595 & \begin{tabular}{|l|l|l|}
$\mid-1$ & - \\
- & $-88-$ \\
\end{tabular} & $\begin{array}{l}\mathrm{A}_{\mathrm{II}} / \mathrm{B}_{\mathrm{II}} / \mathrm{C}_{\mathrm{II}} \quad \text { wh: } \\
\text { (Figure } 2: 3 \text { ) }\end{array}$ & $\begin{array}{l}10 \\
10\end{array}$ & $\begin{array}{r}10 \\
5\end{array}$ & $\overline{85}$ & $\begin{array}{c}80 \\
-\end{array}$ & $\begin{array}{l}- \\
-\end{array}$ & - & $\begin{array}{c}\infty \\
0.06\end{array}$ & $2-98$ \\
\hline $366-29-3,127-130$ & E. Eoc. & 598 & \begin{tabular}{|l|l|}
$1-1-\overline{7}$ \\
$-1-$
\end{tabular} & $A_{I I}$ & 10 & 30 & 10 & 50 & - & - & 3 & $1-20$ \\
\hline $366-31-4,91-93$ & E. Eoc. & 618 & \begin{tabular}{|c|c|}
$-1-x_{1}-$ \\
$1-$
\end{tabular} & ${ }^{B_{I I}} / C_{I I}$ & 15 & 55 & 15 & 5 & 5 & py & 3.7 & 80 \\
\hline $366-41-3,81-83$ & E. Eoc. & 712 & \begin{tabular}{|l|l|l|}
$\mid$ & 1 & 1 \\
-1 & $-81-$ \\
\end{tabular} & $A_{I} / A_{I I}$ & 10 & 10 & 10 & 50 & - & mo & 1 & 8 \\
\hline $\begin{array}{l}366-43-3,90-92 \\
366-47-3,46-48 \\
366-49-3,88-90 \\
366-50-3,117-119 \\
\end{array}$ & Lt. Paleoc. & $\begin{array}{l}731 \\
769 \\
788 \\
798 \\
\end{array}$ & \begin{tabular}{r|r|}
$\mid-1-1-1-$ \\
$-1-\infty$ \\
8
\end{tabular} & $\left\{\begin{array}{l}\mathrm{C}_{\mathrm{II}} \\
\text { (microlenses) }\end{array}\right\} \phi$ & 10 & $<5$ & 15 & 40 & - & $\underline{\mathrm{mo}}$ & 0.2 & 15 \\
\hline $367-10-1,126-128$ & M. Eoc. & 342 & $\mathrm{z}_{-}^{-}-\alpha_{-}^{-}$ & $\begin{array}{l}{ }^{?} \mathrm{~B}_{\mathrm{I}_{2}} \\
\text { (no TS) }\end{array}$ & 5 & 90 & 5 & - & \begin{tabular}{|l} 
SEM: \\
fibers \\
(Plate
\end{tabular} & $\begin{array}{l}\text { : palyg. } \\
\text { s in pores } \\
\text { e 1, Fig. 3) }\end{array}$ & 18 & (no TS) \\
\hline $\begin{array}{l}367-11-1,66-69 \\
367-11-1,70-72\end{array}$ & M. Eoc. & 350 & 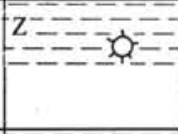 & $\begin{array}{r}\text { lgy: } \\
\text { mgy: } \\
\text { lgy: } \\
\text { dgy: }\end{array}$ & $\begin{array}{l}10 \\
10 \\
15 \\
10\end{array}$ & $\begin{array}{l}55 \\
75 \\
45 \\
60 \\
\end{array}$ & $\begin{array}{r}5 \\
10 \\
5 \\
15 \\
\end{array}$ & $\begin{array}{r}- \\
- \\
10 \\
5\end{array}$ & \begin{tabular}{r|}
5 \\
$<5$ \\
5 \\
$<5$ \\
\end{tabular} & $\begin{array}{l}\text { mo, cl, si } \\
\text { mo, } \mathrm{cl}, \mathrm{si} \\
\text { se }\end{array}$ & \begin{tabular}{|l|}
11 \\
7.5 \\
9 \\
4 \\
\end{tabular} & $\begin{array}{l}\text { in TS } \\
\text { not } \\
\text { identi- } \\
\text { fiable }\end{array}$ \\
\hline $367-12-1,6-8$ & E. Eoc. & 360 & 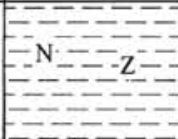 & $\mathrm{B}_{3}$ & 25 & 60 & 5 & $<5$ & 5 & fs & 12 & $\begin{array}{l}\text { in TS } \\
\text { not } \\
\text { identi- } \\
\text { fiable }\end{array}$ \\
\hline
\end{tabular}


TABLE 2 - Continued

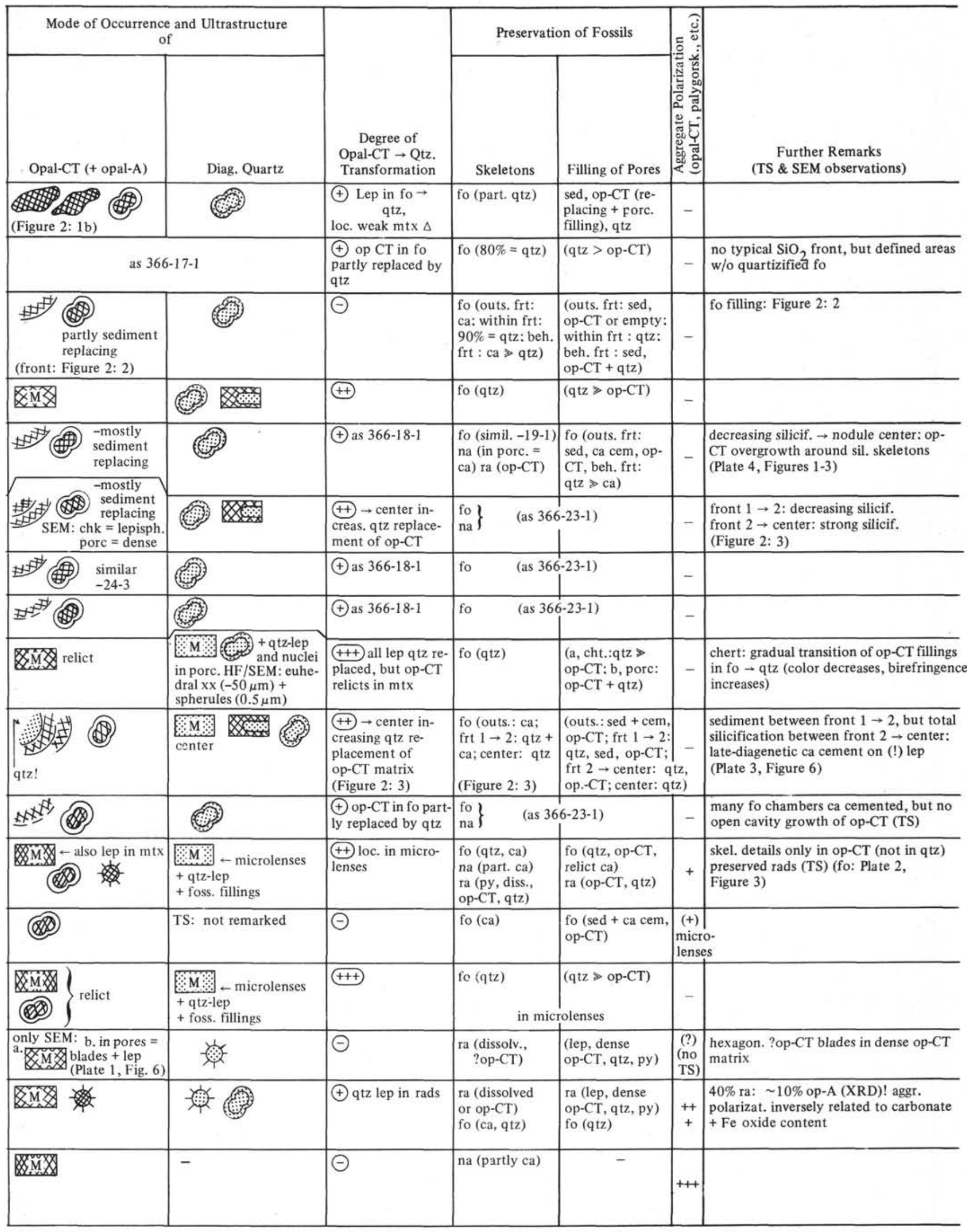


TABLE 2 - Continued

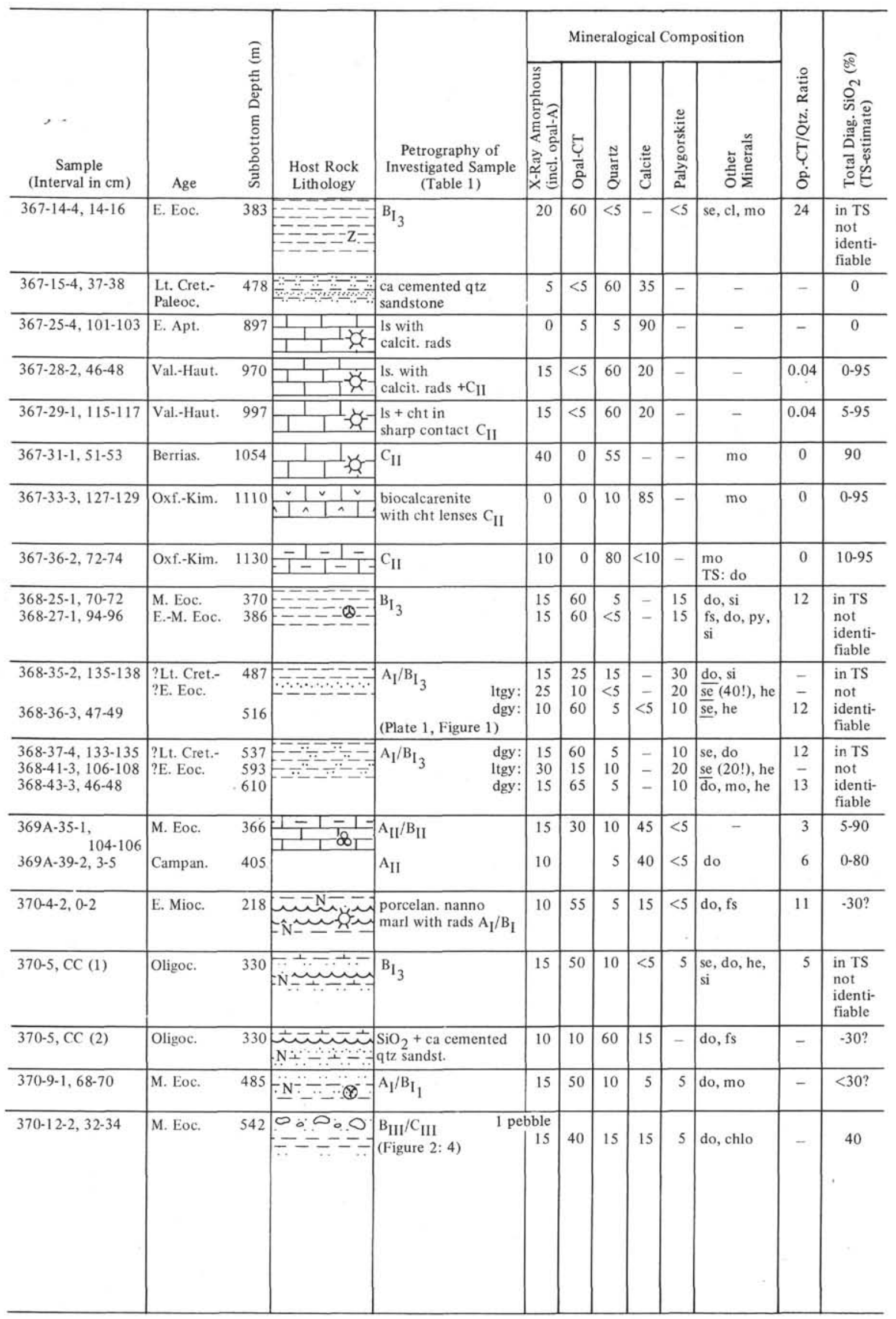


TABLE 2 - Continued

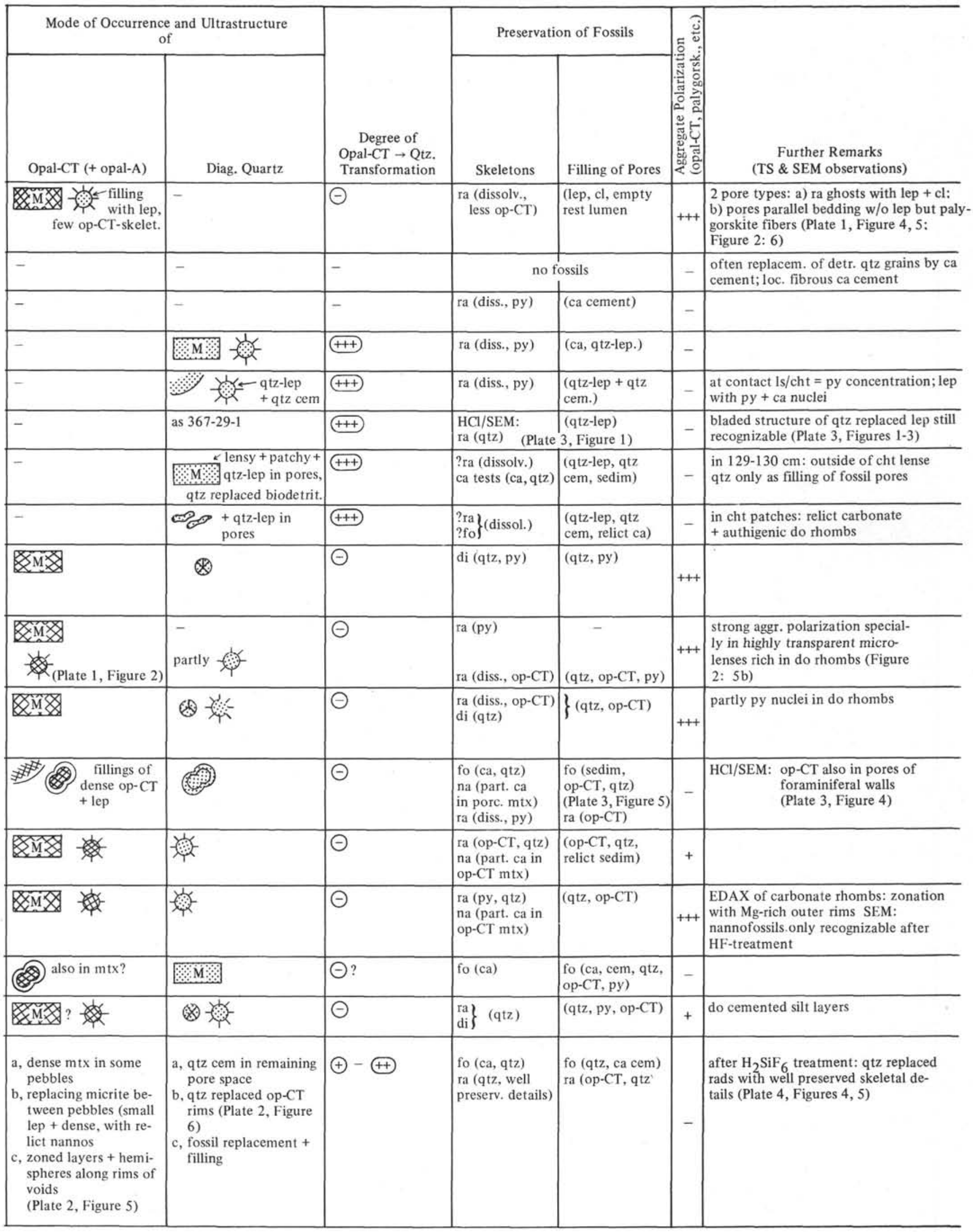


TABLE 2 - Continued

\begin{tabular}{|c|c|c|c|c|c|c|c|c|c|c|c|c|c|}
\hline \multirow[b]{2}{*}{$\begin{array}{c}\text { Sample } \\
\text { (Interval in } \mathrm{cm} \text { ) }\end{array}$} & \multirow[b]{2}{*}{ Age } & \multirow{2}{*}{ 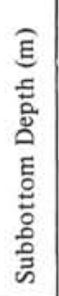 } & \multirow[b]{2}{*}{$\begin{array}{l}\text { Host Rock } \\
\text { Lithology }\end{array}$} & \multirow[b]{2}{*}{$\begin{array}{c}\text { Petrography of } \\
\text { Investigated Sample } \\
\text { (Table 1) }\end{array}$} & \multicolumn{6}{|c|}{ Mineralogical Composition } & \multirow{2}{*}{ 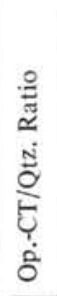 } & \multirow{2}{*}{\multicolumn{2}{|c|}{ 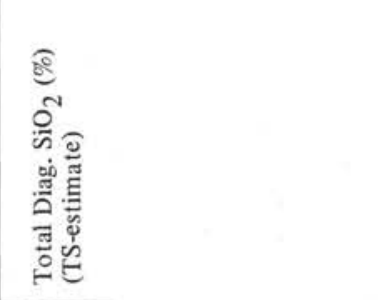 }} \\
\hline & & & & & 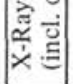 & वै. & 旁 & $\frac{\overrightarrow{0}}{0}$ & $\stackrel{\infty}{\bar{a}}$ & 总总 & & & \\
\hline $370-15-1,42-44$ & M. Eoc. & 588 & 숙요목 & $\mathrm{C}_{\mathrm{II}}\left(\mathrm{B}_{\mathrm{II}}\right)$ & 15 & 50 & 10 & 15 & 5 & do, fs, mo & 5 & 90 & \\
\hline $370-15-2,139-141$ & M. Eoc. & 590 & $\because: \frac{1}{8}: \frac{1}{a}$ & $\begin{array}{ll}\mathrm{B}_{\mathrm{II}} ? / \mathrm{C}_{\mathrm{II}} ? & \mathrm{bl} \\
+ \text { ca cemented } & \mathrm{gy}: \\
\text { pebbly foram. } \\
\text { arenite }\end{array}$ & $-\overline{30}$ & $\overline{5}$ & $\begin{array}{l}95 \\
65\end{array}$ & $\begin{array}{l}- \\
-\end{array}$ & $\begin{array}{ll}- \\
-\end{array}$ & do & $\begin{array}{l}0 \\
0.1\end{array}$ & $90-95$ & \\
\hline $370-17-2,23-25$ & E. Eoc. & 618 & $\begin{array}{l}\mathrm{N} \\
\mathrm{N}\end{array}$ & $\mathrm{A}_{\mathrm{I}} / \mathrm{B}_{3}$ & 10 & 55 & 25 & $<5$ & $<5$ & se, do & - & $\begin{array}{l}\text { in TS } \\
\text { not } \\
\text { identi- } \\
\text { fiable }\end{array}$ & \\
\hline \multicolumn{3}{|c|}{ 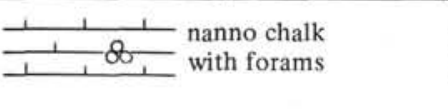 } & \multicolumn{2}{|c|}{ 胥望 } & \multicolumn{6}{|c|}{$\begin{array}{l}-1-1 \text { silty calcareous } \\
----1 \text { diatoms }\end{array}$} & \multicolumn{2}{|c|}{$\begin{array}{l}\mathrm{M} \text { op-CT } \\
\mathrm{qtz}\end{array}$} & matrix \\
\hline 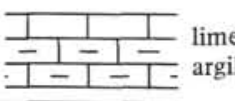 & $\begin{array}{l}\text { estone }+ \\
\text { illaceous ls }\end{array}$ & & 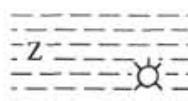 & $\begin{array}{l}\text { zeolitic clay(stone) } \\
\text { with rads }\end{array}$ & & 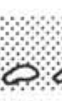 & 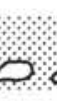 & 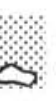 & & $\begin{array}{l}\text { stone }+ \\
\text { lomerate }\end{array}$ & & $x$ & $\begin{array}{l}\text { op-CT mtx with qtz } \\
\text { nuclei }+ \text { cht microlenses }\end{array}$ \\
\hline
\end{tabular}

Note: $(1)$ color: $w h=$ white, lgy $=$ light gray, $\mathrm{dgy}=$ dark gray, $\mathrm{mgy}=$ medium gray, $\mathrm{bl}=$ black. (2) semi-quantitative mineralogical composition: parentheses $=<2 \%$, no mark $=2$ to $10 \%$, underline $=>10 \%$. (3) minerals: qtz $=$ quartz, op-CT $=$ opal-CT, op-A $=$ opal-A, ca $=$ calcite, do $=$ dolomite, $\mathrm{py}=$ pyrite, $\mathrm{se}=$ sepiolite, $\mathrm{mo}=$ montmorillonite, $\mathrm{cl}=$ clinoptilolite, $\mathrm{chlo}=$ chlorite, $\mathrm{he}=$ hematite, $\mathrm{si}=\mathrm{siderite}, \mathrm{fs}=\mathrm{feld}$ spar .

The SEM investigations of quartz-replaced radiolarians show exceptionally good preservation in clayey sediments (Plate 4, Figures 4, 5). The quartz surfaces are slightly granular (on the order of a few microns) and some are covered by tiny, 1 to $2 \mu \mathrm{m}$ long rods with a diameter of $0.1 \mu \mathrm{m}$.

In addition to the preservation stages discussed above, there are also completely dissolved ("ghosts") and pyritized skeletons. These skeletons are sometimes filled by sediment, calcitic cement, opal-CT rim cement + lepispheres (sometimes quartz-replaced), chalcedonic quartz, clinoptilolite, or pyrite (Figure 2: 6,8).

\section{Other Diagenetic Constituents}

Euhedral to subhedral dolomite rhombs up to $60 \mu \mathrm{m}$ in diameter, are frequent (up to $15 \%$ ) in the palygorskite-rich porcellanites (Figure 2: 8). Some of the dolomite rhombs have a pyritic core (possibly derived from a carbonaceous nucleus, $\mathrm{cf}$. Berger and von Rad, 1972). Some rhombs show a zonation. An elemental determination by energy-dispersive X-ray analysis shows a distinct, continuous increase of the amount of $\mathrm{Mg}$ from the center to the rim of a rhomb. This suggests that the availability of $\mathrm{Mg}$ ions was increased during the period of growth of the carbonate rhomb.

Clinoptilolite is relatively rare. It usually occurs in radiolarian ghosts together with opal-CT lepispheres and pyrite. Clinoptilolite appears in most cases to be one of the latest diagenetic void-filling minerals, and probably younger than the lepispheres.

\section{Carbonate Environment (nodular porcellanites and quartz cherts)}

Weakly silicified chalks (Table 1: A II), nodular porcellanites ("embryo flints" after Bromley et al., 1975; B II), and nodular quartz cherts ("flints"; C II) are typical of the carbonate environment (Table 1; Figure 6). They originated by localized silica concentration in foraminiferal nanno ooze, chalk, and marl, in radiolarian-bearing argillaceous limestone, and related carbonate-rich lithologies. These types of silicified sediments occur especially in the pelagic Eocene siliceous limestone/chalk section of Site 366, in the deep-water Oxfordian to Neocomian limestone/marlstone sequence of Site 367, and in the hemipelagic Maestrichtian to Eocene nanno marlstone of Site 369. The porcellanite/chert boundary is at about $50 \mathrm{~m} . \mathrm{y}$. (Eocene) in Sites 366, 369, and 370, and drops to below 100 m.y. at Sites 367 and 368 (Figure 1).

Thus, all progressive stages of silicification in the carbonate environment can be studied in some of the Leg 41 sites, starting from weakly silicified chalk with only silica-replaced fossils (Figure 2: 1a), and progressing to types with patchy silicification of the matrix (Figure 2: 1b), and finally to nodular porcellanites and quartz cherts with single (Figure 2: 2) or multiple silicification fronts (Figure 2: 3 ).

\section{Weakly Silicified Chalks With Silica-replaced Fossils}

Other than the more or less sporadic growth of opalCT lepispheres in small voids, the silicification of 
TABLE 2 - Continued

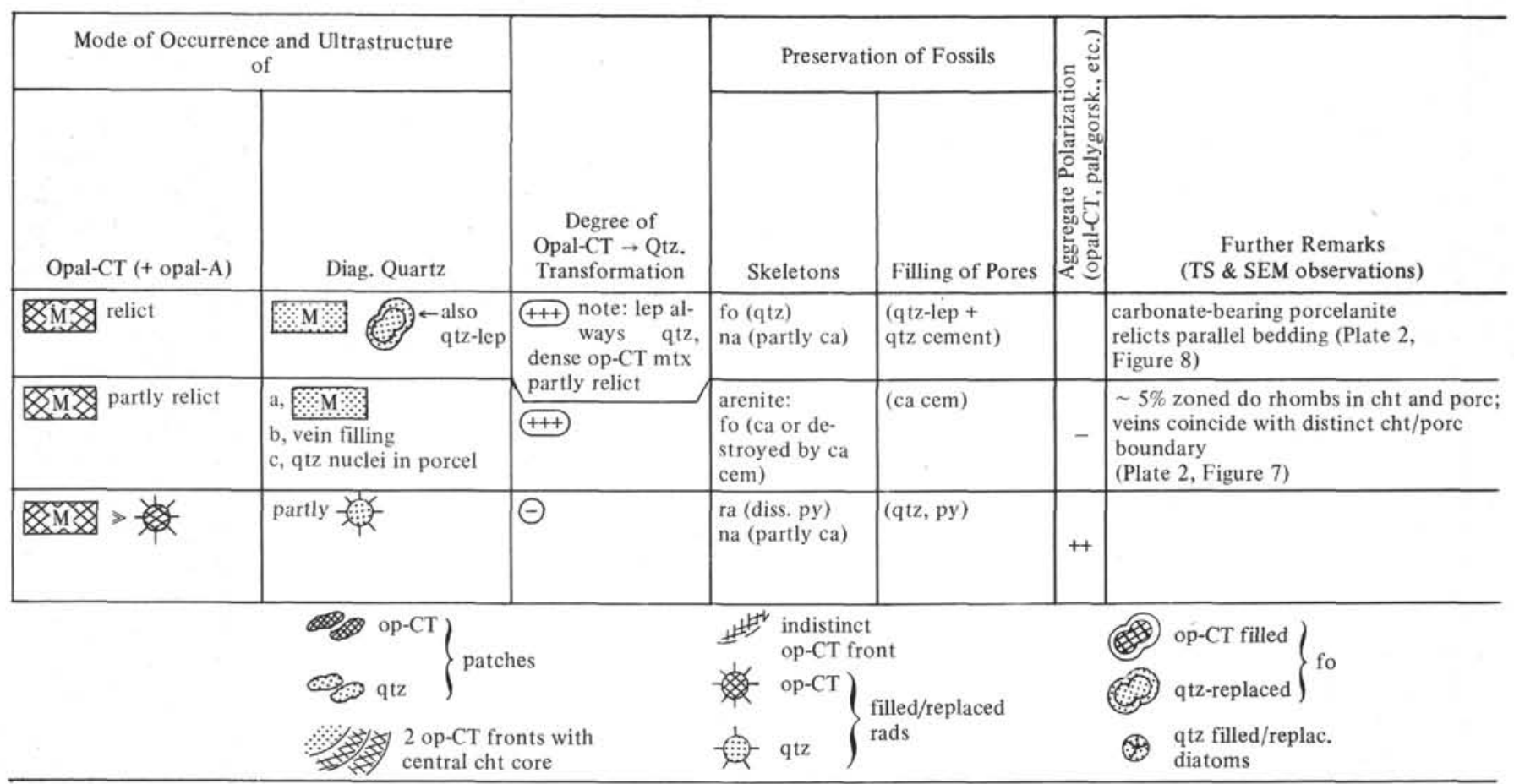

(4) opal-CT $\rightarrow$ quartz transformation + aggregate polarization: $-=$ none, $+=$ weak, $++=$ medium, $+++=$ strong. $(5)$ fossils: fo $=$ foraminifera, $\mathrm{ra}=$ radiolarians, $\mathrm{di}=$ diatoms, $\mathrm{na}=$ nannofossils. $(6)$ methods: $\mathrm{TS}=$ thin-section, $\mathrm{SEM}=$ scanning electron microscopy, $\mathrm{EDAX}=\mathrm{energy}$ dispersive X-ray analysis; $\mathrm{HCl}, \mathrm{HF}, \mathrm{H}_{2} \mathrm{SiF}_{6}=$ acid treatment. (7) Further abbreviations: chk $=$ chalk, $1 \mathrm{~s}=$ limestone.

calcareous ooze and chalk is restricted to the replacement or filling of foraminiferal tests and chambers by silica. The open cavities of the foraminifera are often lined by a rim cement of opal-CT lepispheres. Opal-CT often replaces even the original micritic filling of the fossil (Figure 2: 1a) possibly due to minor compaction and higher porosity of the sediment within the foraminiferal chamber. The foraminiferal tests themselves and calcitic cement in the chambers are always replaced by chalcedonic quartz, not by opal-CT. Only the pores of the foraminiferal walls are locally lined or closed by individual opal-CT lepispheres or dense opal-CT (Plate 3, Figure 4). If calcitic portions of the foraminiferal tests are preserved, then a centrifugal (outward-directed) or centripetal (inward-directed) replacement by quartz is seen.

\section{Weakly Silicified Chalks With Patchy Silicification}

Certain calcareous nannofossils remain surprisingly well preserved during silicification for remarkably long time intervals. The mechanisms which allow this preservation are not known. Nannofossils are easily recognized in an opal-CT matrix even in thin sections (Figure 2: 9a).

\section{Nodular Porcellanite and Quartz Cherts With Silicification Fronts}

If the silicification process has progressed further, then opal-CT fills the sediment pores to a larger degree and replaces the nearby calcareous sediment (Figure 2: $1 b)$. This produces a diffuse, patchy replacement of carbonate by opal-CT, whereas the associated unsilicified chalk shows a patina of concentrated dark material (clay, iron oxides, or organic matter).
A more or less distinct opal-CT/chalk front (Figure 2: 2) is formed in addition to the general silicification of microfossils and of porcellanitic patches if the intensity of "chertification" is further advanced. This irregular, ellipsoidal front encloses a sediment lens which consists either of original chalk, silicified microfossils, or a core of quartz chert (Figure 2: 3 ). There is usually a dirty rim of fine-grained impurities outside the silicification front, probably composed of clay minerals and iron oxides pushed aside and concentrated by the replacement process (Figure 2: 2). The porosity (as observed in SEM) decreases drastically across the chalk/porcellanite boundary.

In the case of multiple silicification fronts (up to three fronts were observed) the situation is more complex. The intensity of silicification decreases from the outer to the intermediate front (Figure 2: 3, area II). The innermost front separates porcellanite from quartz chert in the nodule center (area IV). The innermost front is "secondary" because this quartz chert contains many porcellanite relicts. The following observations were made (Figure 2: 3) regarding the silicification of foraminifera outside and inside those fronts:

\begin{tabular}{lll}
\hline Area & $\begin{array}{c}\text { Composition of } \\
\text { Foraminiferal Tests }\end{array}$ & $\begin{array}{c}\text { Composition of Foraminiferal } \\
\text { Chamber Fillings }\end{array}$ \\
\hline I & Calcite & $\begin{array}{l}\text { Micrite, calcite cement (B), } \\
\text { opal-CT }\end{array}$ \\
II & Quartz + calcite & Quartz, opal-CT, micrite \\
III & Quartz & Quartz, opal-CT \\
IV & Quartz & Quartz, relict opal-CT \\
\hline
\end{tabular}


It is especially noteworthy that no quartz was observed in chalk outside the fronts (area I) and no latediagenetic calcitic-mosaic cement was found in nodules (areas II-IV).

The proportion of the $\mathrm{SiO}_{2}$-modifications is likely to vary widely on a very fine scale because of the highly complex zonation of these silica nodules. This limits the usefulness of the opal-CT to quartz ratio, estimated from XRD analyses.

\section{Silica-cemented Conglomerates (B/C III)}

A silica-cemented, poorly sorted conglomerate with fragments of porcellanite, shale, and micritic limestone was observed in middle Eocene turbidites at Site 370 (Figure 2: 4; Plate 2, Figures 5, 6). The silica cement consists of: (a) opal-CT, either structureless or lepispheres (5 to $10 \mu \mathrm{m}$ ) with relict carbonate sediment (nannofossils, etc.). This opal-CT has obviously replaced original micritic matrix filling the interstices between the pebbles; (b) zoned opal-CT (partly replaced by quartz) as rim (A-) cement or hemispheres (up to $80 \mu \mathrm{m}$ ) lining cavity walls (Plate 2, Figures 5, 6); and (c) microcrystalline or chalcedonic quartz (Bcement) filling the remaining pore space.

\section{Transition Porcellanite $\rightarrow$ Quartz Chert}

Opal-CT relicts can frequently be recognized (Figure 2: 9, 10; Plate 2, Figures 7,8) within the matrix and microfossils of the younger nodular quartz cherts (flints). The opal-CT precursor is indicated only in local pores as single quartz pseudomorphs after opal-CT lepispheres within the older cherts (Plate 3, Figures 13 ). An original opal-CT stage of the quartz matrix cannot be demonstrated, but it is highly probable based on comparisons with analogous younger quartz cherts which are still in a transitional stage between opal-CT and quartz.

\section{Quartz-replaced Lepispheres and Siliceous Organisms}

Quartz pseudomorphs after opal-CT lepispheres can be morphologically recognized in most quartz cherts, even in those of Oxfordian to Kimmeridgian age (Figure 2: 10; Plate 3, Figures 1-3). This is the first step in the late diagenetic opal-CT $\rightarrow$ quartz transformation (Figure 6; see also Keene, 1975, pl. 12). The transformation must have taken place more or less in situ because the outer spherical shape is well preserved. Only the ultrastructure of the lepispheres is destroyed. The blades disappear more or less and the surfaces of the spherules show a smooth or finely granular texture $(0.25-2 \mu \mathrm{m})$ (Plate 3 , Figure 3$)$. The silicified sediments of the clayey facies (B I) rarely show a replacement of void-filling lepispheres by quartz, nor is their matrix transformed into quartz.

\section{Quartz-replaced Matrix}

The porcellanite to chert transition is completed by the gradual replacement of the opal-CT matrix by quartz during late diagenesis (Figure 6). In general, the transition of porcellanite to quartz chert is accompanied by a strong decrease of pigmentation and a more or less complete destruction of primary sedi- mentary particles. Thus, the transparency of a hand specimen can be a useful criterion for the macroscopic determination of quartz cherts. A few "dirty" cherts (e.g., those associated with marlstones), however, can preserve a "porcelaneous" appearance for some time. Gradually, however, these cherts become more and more purified and homogenized. Only authigenic dolomite rhombs (5\%-10\%), formed during the porcellanite stages and pyrite was preserved in the laterformed quartz chert.

Sedimentary structures are completely destroyed during chertification in the carbonate-rich silicified rocks. However, finely laminated cherts occur in marly and clayey lithologies. The lamination in these cases is produced by the preservation of layered dark pigments rather than by the texture of the quartz crystallites. The weak aggregate polarization of marly to clayey porcellanites is almost completely lost during the transformation into quartz chert.

A few uncemented pores in some rocks are still left open after complete chertification. Dense opal-CT fillings of foraminifera are sometimes porcellanitic relicts in cherts (Figure 2: 10). In one thin section (36629-1), the complete transitional replacement series of opal-CT into quartz was found:

Stage I shows filling of foraminiferal chambers by opal-CT, well recognizable by a light brownish color within the transparent quartz matrix.

In Stage II $\sim 50 \%$ of the chamber filling consists of opal-CT, the rest of quartz. The brownish color is less distinct and some birefringence is observable in microenvironments, but no distinct quartz grains occur.

Stage III shows filling of quartz, but the crystallite size is smaller than in the surrounding matrix. The filling can be distinguished from matrix only under crossed nicols.

The progressive development of small quartz nuclei (a few $\mu \mathrm{m}$ in diameter) can be recognized in the fillings of foraminifera and in the porcelaneous matrix of various samples (366-21-2, 370-15-2, 370-17-2; Plate 2, Figure 7). Again, the amount of quartz crystallites is inversely proportional to the concentration of dark impurities. The transition of highly pigmented, "impure" porcellanites with few quartz nuclei into a homogenized quartz chert is schematically shown in Figure 2 (9b: 1-3).

Abrupt juxtapositions of porcellanite and chert exists along quartz-filled veins (Figure 2: 9a, b; Plate 2, Figure 7). The porcellanitic relicts in laminated cherts occur as elongated lenses along the bedding plane. The opal-CT to quartz transformation in zoned porcellanite nodules starts in the center by forming chert patches, bands, or microlenses ("centrifugal" chertification; Figure 2: 3).

\section{MINERALOGY OF OPAL-A AND OPAL-CT}

\section{Opal-A}

The determination of opal-A in the presence of opalCT is still one of the main problems in an X-rayanalysis of weakly silicified sediments and porcellanites (von Rad and Rösch, 1974). 
The standard used for the determination of opal-A (Australian potch opal) has one broad peak between $2.8 \AA$ and $6 \AA$ and a maximum at about $4 \AA$. The X-ray trace of opal-A in siliceous DSDP sediments shows this feature. But it is not known whether there are other Xray amorphous phases (e.g., organic compounds, amorphous clay minerals) in addition to the opaline silica, that contribute to this bulk area. This uncertainty is confirmed by thin section and SEM observations which usually suggest much smaller opal-A contents than do the X-ray results. The percentages of opal-A and other X-ray amorphous material had to be combined in Table 2 to overcome these difficulties and should be viewed with caution. Therefore, the percentages of X-ray amorphous material (inclusive opal-A) of Table 2 represent maximum contents of opal-A!

The procedure used to split the opal-CT and opal-A peak areas at about $4.1 \AA$ is illustrated in Figure 3. The dotted line represents a mixture between pure opal-A and pure opal-CT. The more or less significant bend of the slope (at A) marks the position where the separation line between the peak areas of opal-A and opal-CT is drawn.

\section{Opal-CT}

\section{Maturation of the Opal-CT Structure}

Murata and Larson (1975) point out a variation of the $d=4.1 \AA$ spacing of opal-CT with depth in the Monterey Shale of Southern California, called by them "cristobalite (101)." They attribute this to a progressive diagenetic ordering of the atomic structure favored by increased temperature and pressure. Consequently, they use the numerical $d$ value as an index of structural state in order to more accurately characterize the disorder which accompanies the diagenetic transformation of opal-CT.

Precise $d$ measurements of the opal-CT $4.1 \AA$ spacing using the porcellanites and cherts of Sites 368 and 370 (with a wide range of burial depths) yields similar results (Figure $4 \mathrm{a}, \mathrm{b}$ ). There is an obvious correlation between burial depth and structural state of the opalCT, although a few individual measurements do not comply with this general trend. It should be noted that the gradient and shape of the curves are different for the two sites. Possibly, the gradient increases below 400-500 meters (Eocene). Thus, if temperature variations produced by increasing burial depth influenced the crystal lattice, then the speed of this diagenetic process was probably also influenced by additional, but unknown factors.

Murata and Nakata (1974) found separate $d$ values for opal-CT in porcellanites and associated cherts. This phenomenon appears not to be valid for the two sites investigated here.

\section{Ultrastructure and Crystallographic Interpretation of Lepispheres}

Lepispheres, microspherical clusters of bladed hexagonal opal-CT crystallites (Wise and Kelts, 1972), are among the most interesting and conspicuous

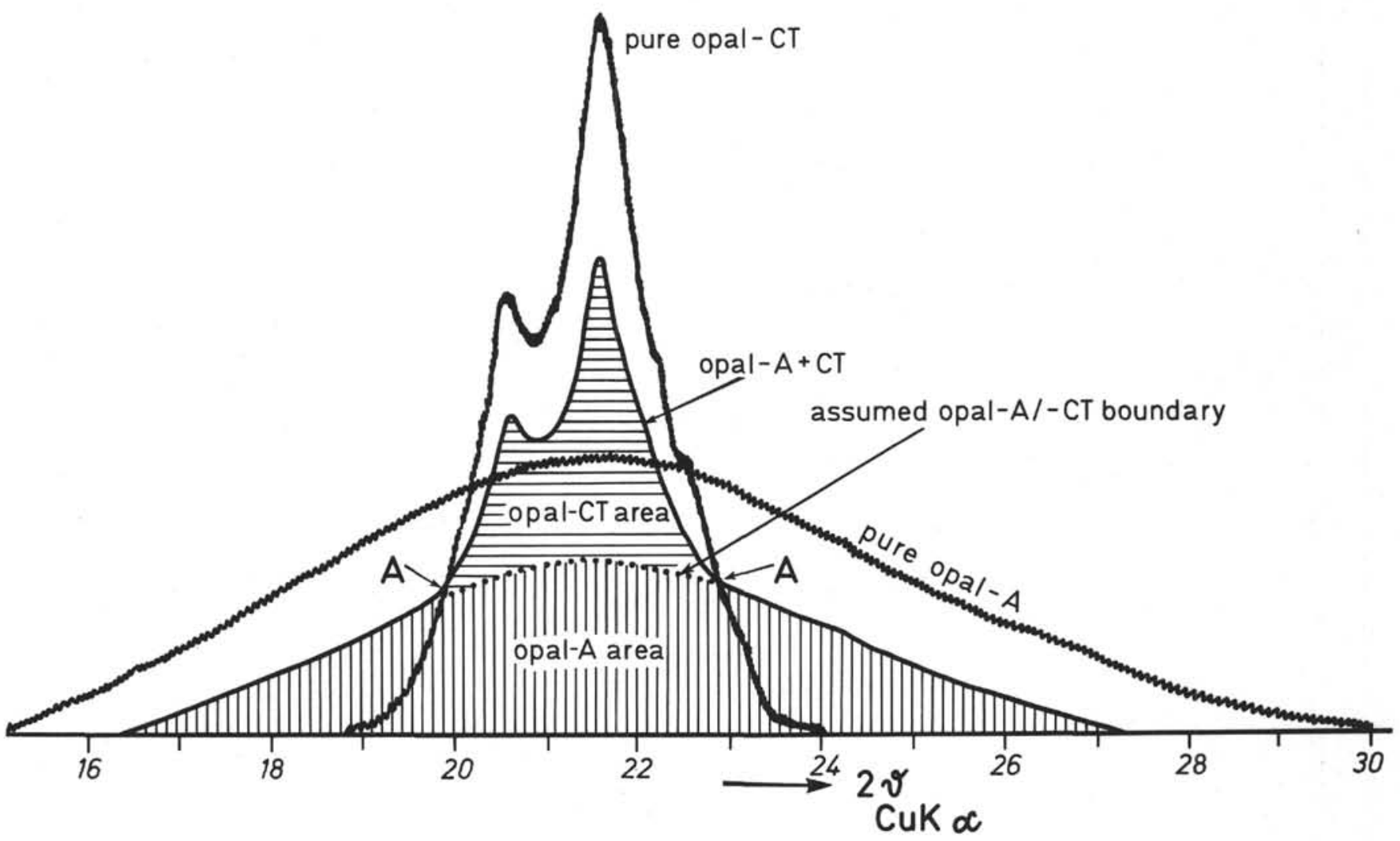

Figure 3. Estimation of the opal-A and opal-CT peak areas from XRD traces of opal-A+CT mixtures. $A=$ bend of slope through which opal-A/-CT boundary is drawn. 
U. VON RAD, V. RIECH, H. RÖSCH

${ }^{\circ} 2 \vartheta_{C u K \alpha, \text { Cristob.(101) }}$

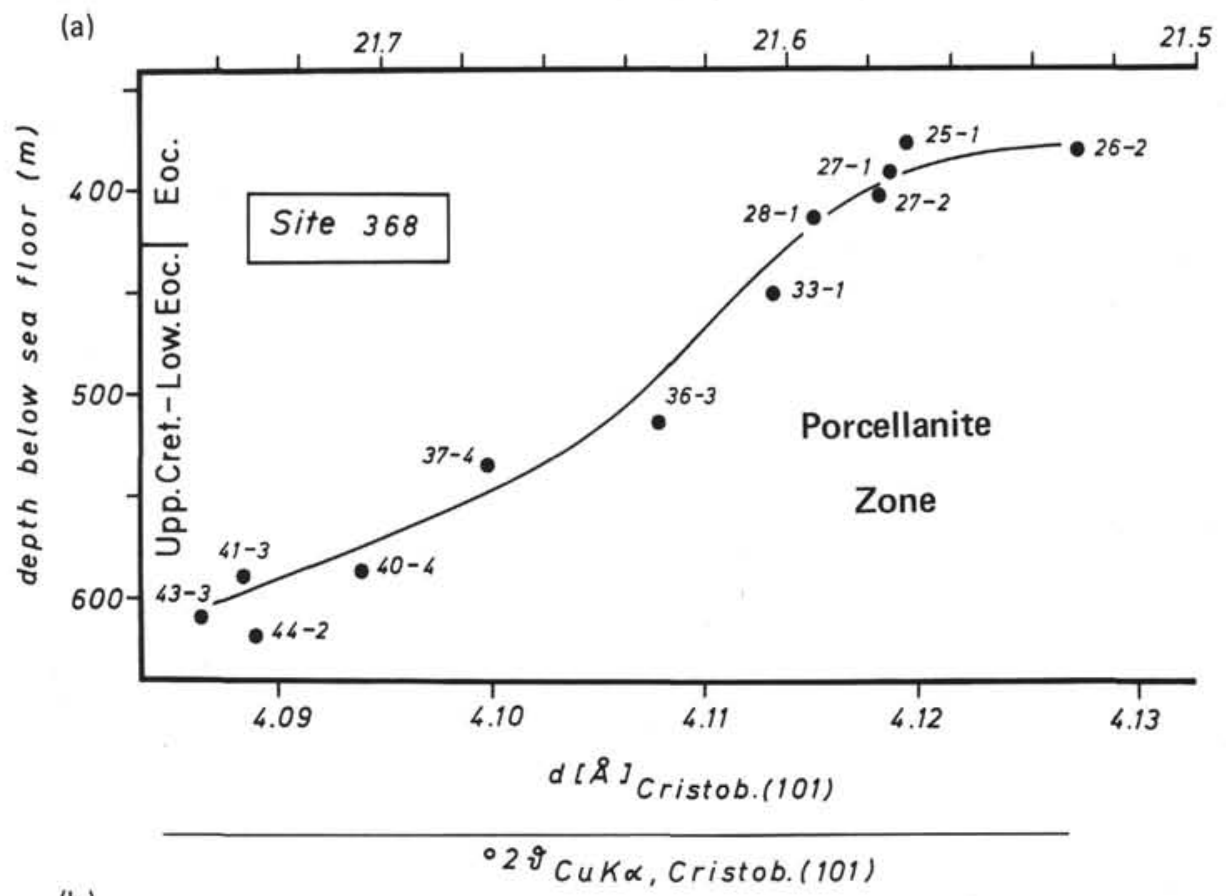

(b)

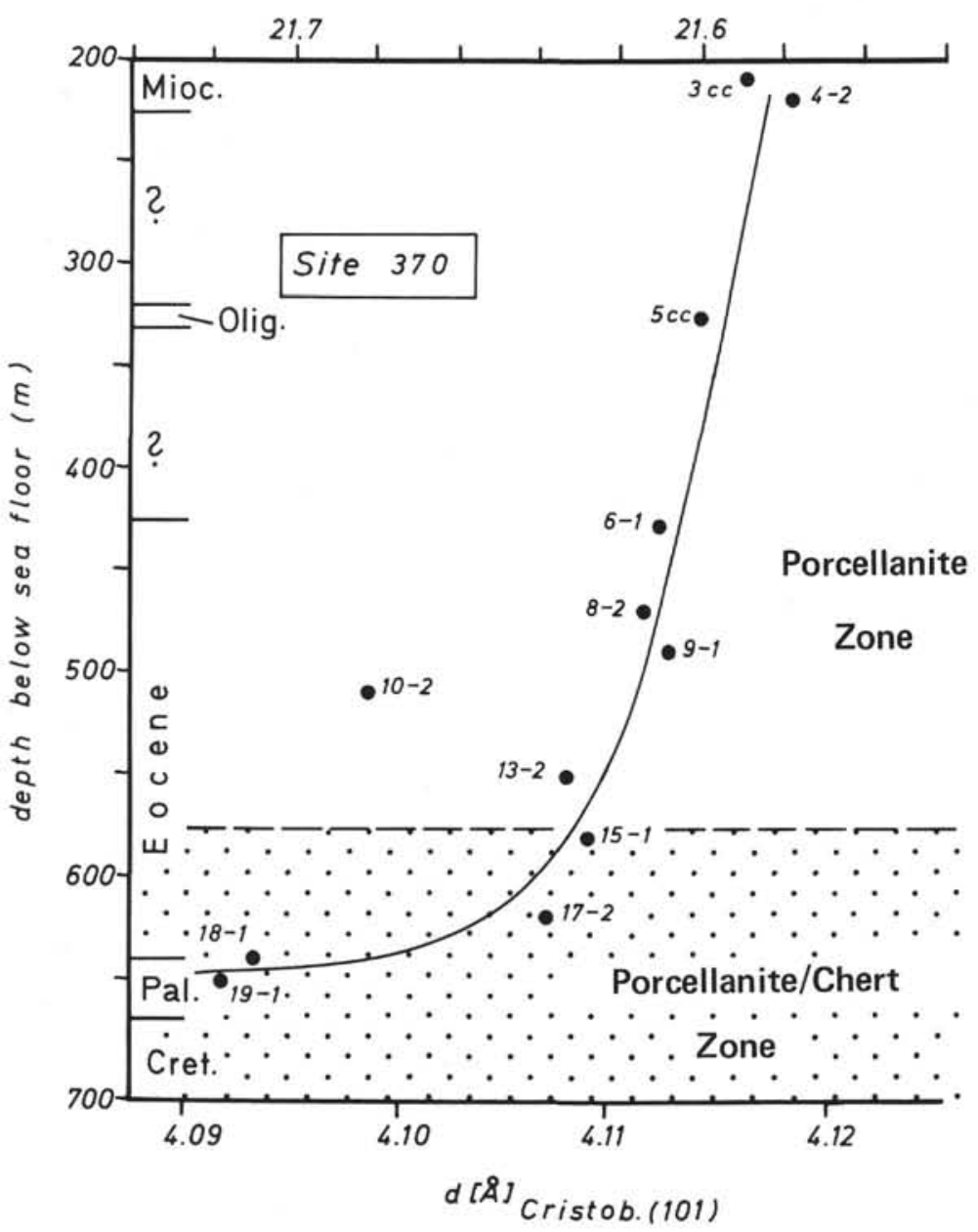

Figure 4. Maturation of opal-CT in Sites $368(a)$ and $370(b)$ using the precise position of the d(101)-cristobalite XRD peak near 4.1 (Murata and Nakata, 1974). 
discoveries from DSDP samples. They are not an arbitrary cluster of spherulitic, fibrous, radiated, or randomly intergrown crystallites (Weaver and Wise, 1972; von Rad and Rösch, 1974; Oehler, 1973). Their ultrastructure consists of regularly interpenetrated opal-CT blades governed by the complex (3034) and (1016) twinning laws of tridymite. The typical structure and the underlying twinning law is illustrated in Figure 5. The basal pinacoid of tridymite corresponds to the cristobalite octahedron (Figure 5a). Multiple intergrowth of equivalent faces with intersection angles of $70^{\circ} 32^{\prime}$ or $180^{\circ}$ minus $70^{\circ} 32^{\prime}$ lead to pseudocubic forms showing the typical "cardhouse" stacking structure of lepispheres. Figure $5 \mathrm{~b}$ shows, in a generalized fashion, a typical "incipient lepisphere" with a regular interpenetration of ragged-edged opal-CT blades in three directions ( $\mathrm{A}, \mathrm{B}$, and $\mathrm{C})$. This phenomenon and the principles of lepisphere development are discussed in more detail by Flörke et al. (1976).

Transmission electron microscopy (TEM) was used to determine the nature of the individual blades building up the opal-CT lepispheres. Lepispheres are very small (about $5 \mu \mathrm{m}$ ) constituents of porcellanites and it was impossible to isolate a sufficient quantity of pure lepispheres for $\mathrm{X}$-ray determination. The main part of opal-CT consists of dense material in the structureless matrix. TEM bright field images of single lepispheres, isolated by $\mathrm{H}_{2} \mathrm{SiF}_{6}$ treatment, did not yield detailed information, because the aggregates remain inpenetrable and opaque (Plate 2, Figure 1).
However, the electron diffraction images of complete lepispheres, as well as of single blades from smashed lepispheres, showed the disordered diffraction pattern of opal-CT (Plate 2, Figure 2).

\section{SUMMARY AND SILICA DIAGENESIS}

\section{Sources of Silica}

Amorphous silica is introduced into the deep-sea sediments by various sources (Figure 6). The biogenous opal-A in sediments from the high-productivity (upwelling!) environment of the West African continental margin was derived from siliceous skeletons of diatoms, radiolarians, and sponge spicules. The devitrification of volcanic glass or the submarine degradation of clay minerals are potential silica sources of secondary importance.

\section{Early-diagenetic Opal-A $\rightarrow$ Opal-CT Transformation}

No siliceous skeletons are preserved as opal-A in the pre-middle Miocene sediments studied. Siliceous organisms have been either dissolved or converted into opal-CT or quartz (Figure 6). Relatively high contents of opal-A, determined by XRD analyses (Table 2), probably also include considerable amounts of other Xray amorphous material.

Eocene opal-A radiolarian skeletons have been replaced in situ by opal-CT crystallites (Figure 6; Plate 4, Figures 1-3). Diatoms and sponge spicules are always replaced by quartz.

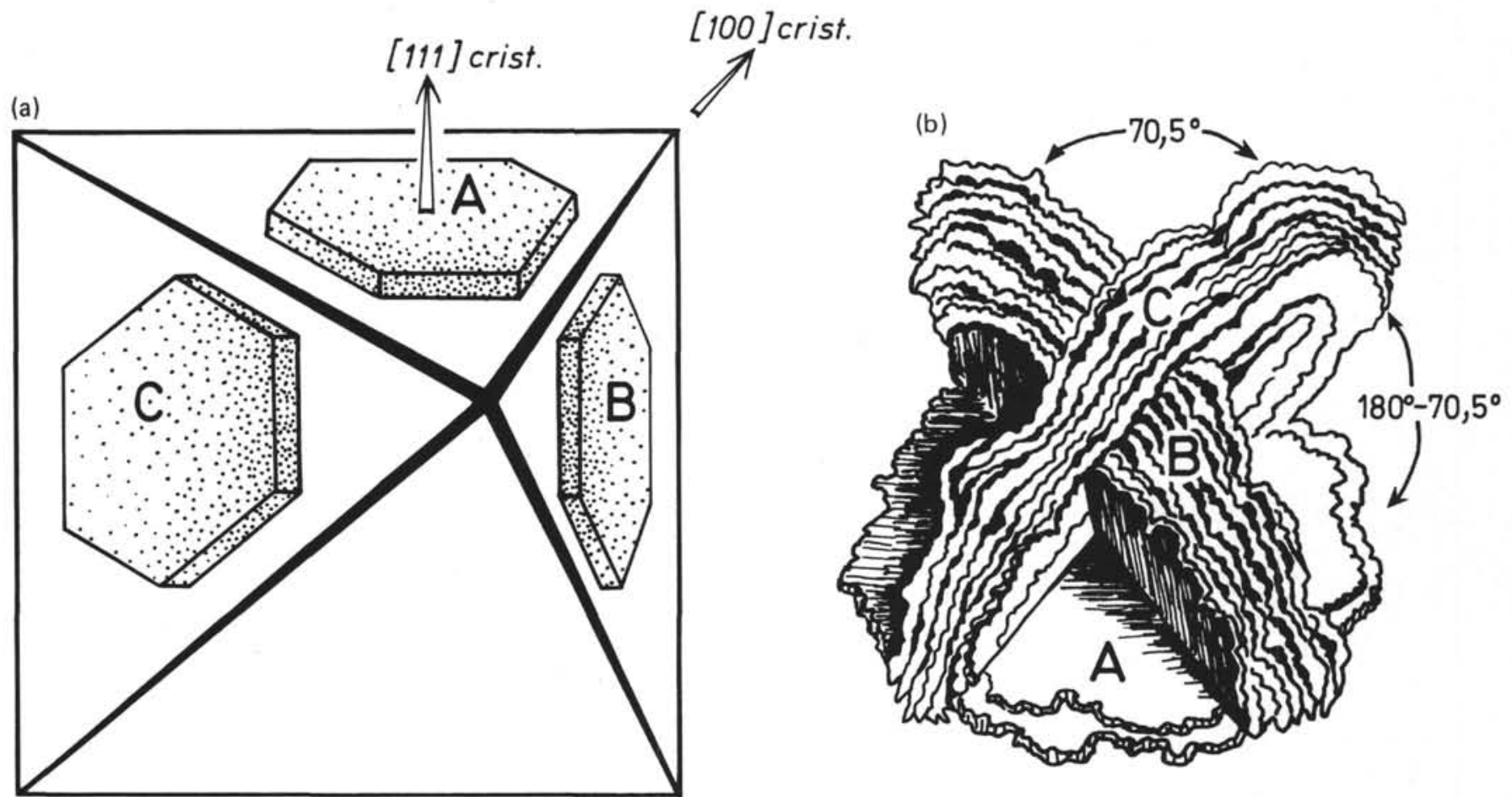

Figure 5. Ultrastructure of opal-CT lepispheres. (a) Three hexagonal tridymite plates (basal/pinacoids) on a cristobalite octahedron, indicating tridymite-type twinning of opal-CT. (b) schematic sketch of "incipient" lepisphere with subparallel opal-CT blades (rounded, ragged edges) oriented parallel to the three directions of the tridymite plates (A, B, C) in Figure 5a. Note the constant angle of $70.5^{\circ}$ (or 180 minus $70.5^{\circ}$ ) between those blade directions and the three-dimensional skeleton with a pseudo-cubic habit ("card house stacking"). 


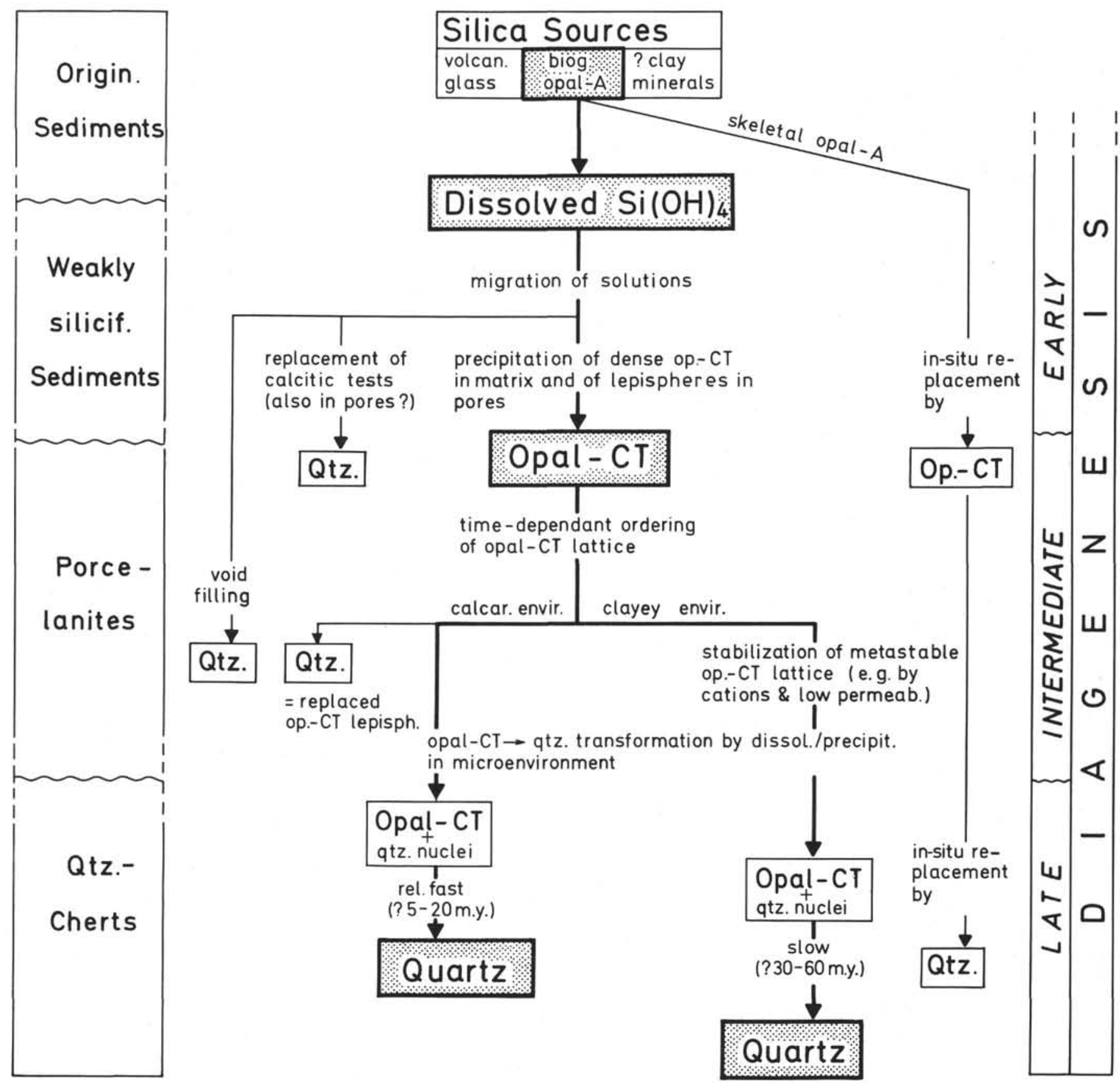

Figure 6. Schematic diagram showing transformations and diagenetic processes between opal-A, opal-CT, and quartz. The vertical position of the silica phases within the diagram attempts to relate them according to their diagenetic evolution (right-hand column). A direct formation of quartz cherts without a porcellanite precursor was not identified.

\section{Ultrastructure of Opal-CT Lepispheres}

Electron diffractometry reveals that lepispheres are composed of opal-CT. The ultrastructure of those lepispheres is governed by complex tridymite twinning laws, resulting in a typical card-house structure built up by a regular interpenetration of platy opal-CT crystallites (Figure 5).

\section{Early-diagenetic Quartz Precipitation in Calcareous Fossils}

Calcitic tests of foraminifera and mosaic cement in their chambers are always replaced by quartz, not by
opal-CT (Keene, 1975). This phenomenon may be caused by the chemical composition of the calcite and the biogenic carbonate.

If silicification fronts are developed, then quartzreplaced foraminifera are present only in the nodular porcellanite inside the front. The foraminifera outside the front are preserved as calcite and are locally filled by opal-CT.

It is remarkable that no late-diagenetic calcite cement was observed inside the porcellanite fronts. The lack of this calcite cement can be explained by crystallization of quartz within the fossil pores-after calcite cementA and opal-CT lepispheres (Plate 3, Figures 5, 6; Plate 
2, Figure 3) or by secondary replacement of calcite cement by quartz.

Foraminifera may be valuable indicators of the concentration of silica in the pore solutions. The silica concentration in weakly silicified chalk (AII) surrounding porcellanitic nodules, was probably too low for quartz replacement of calcitic tests but high enough for local replacement of micritic sediment and filling of pores by opal-CT. This observation disagrees with Kastner and Keene's (1975) experimental results which suggest that direct precipitation of quartz is favored by relatively low silica concentrations, and opal-CT is precipitated from high silica concentrations.

\section{Formation of Silicification Fronts (intermediate diagenesis)}

The first step in silicification is the local formation of lepispheres in voids and a patchy replacement of the carbonate matrix by opal-CT. One or more silicification fronts may develop because of an increase or periodic variations of the input of silica-rich pore solutions. Those fronts progress by centrifugal migration outwards from a core. Thus, an outward (centrifugal) decreasing age of the fronts is paralleled by an inward (centripetal) increase of the intensity of diagenetic evolution (Aubry, 1975). The replacement of opal-CT by quartz starts from the "primary" innermost front (or core of the nodule) outwards (Wise and Weaver, 1974). The distance to the previous front may be influenced by the width of the less-permeable patina of impurities. Most of the un- or weakly silicified sediment zones within the nodules are progressively silicified by the accretion of additional opal-CT fronts.

\section{Precipitation of Authigenic Silicates in Bedded Porcellanites}

Palygorskite and sepiolite-rich, more or less silicified sediments have been encountered in the Eocene sections of many West African coastal basins (Millot, 1970), and in Latest Cretaceous to Paleogene sections of many DSDP sites (e.g., 12, 137, 138, 139, 140, 141, $367,368,370$; Berger and von Rad, 1972) off northwest Africa between $12^{\circ}$ and $34^{\circ} \mathrm{N}$ and between a few hundred to $1000 \mathrm{~km}$ offshore. Possibly, these silicates were not reworked from the African continent, but rather are of authigenic origin. This process involves contemporaneous precipitation of opal-CT and palygorskite/sepiolite from silica-, $\mathrm{Mg}$ - and $\mathrm{Al}-$ oversaturated alkaline solutions in a clayey marine environment (see Millot, 1970, p. 199-203, p. 262-272). Oriented growth of palygorskite/sepiolite fibers and of opal-CT blades parallel to the bedding during intermediate diagenesis and moderate burial conditions may produce the "aggregate polarization" effect typical of most bedded porcellanites. Further investigations are necessary to substantiate this hypothesis.

\section{Late Diagenetic Opal-CT $\rightarrow$ Quartz Transformation}

Millot (1970), Lancelot (1973), and Kastner and Keene (1975) emphasize that the direct crystallization of quartz without an opal-CT precursor might be possible under certain conditions, such as low silica concentrations in the pore waters (e.g., in the quartzose nodule center), carbonate host rock lithologies (no inhibiting foreign cations), and high permeabilities. However, according to Keene (1975, p. 447), opal-CT is usually the first silica phase to precipitate in the carbonate and clay environment. This agrees with our observations which indicate that typical quartz cherts can develop only by gradual maturation from porcellanites and not by direct precipitation without an opal-CT precursor (Figure 6). This is supported by the lack of very young (post-Eocene) quartz cherts, by continuous porcellanite-chert transitions in younger silicified rocks, and by quartz-replaced opal-CT lepispheres in former pores.

Direct precipitation of quartz or direct replacement of calcareous fossil tests by quartz takes place during early or intermediate diagenesis in two restricted microenvironments (Keene, 1975): (a) replacement of foraminiferal tests and of calcitic B-cement, and (b) precipitation in interstitial voids. This precipitation was often predated by an opal-CT rim cement lining cavity walls. Often two generations of silica cements $(A=$ opal$\mathrm{CT}$ rim cement and $\mathrm{B}=$ quartz mosaic cement) separated by a major hiatus, are observed (Plate 2, Figure 3).

A progressive diagenetic maturation of the opal-CT structure within the porcellanite stage is suggested by the positive correlation of the opal-CT $4.1 \AA$ spacing with burial depth (Figure $4 a, b)$. A temperature- and time-dependent influence on the metastable crystal structural state of opal-CT is obvious. This relation supports the "opal maturation theory" (von Rad and Rösch, 1972, 1974). Further investigations are necessary to explain the crystallographical mechanism of structural ordering, before a stacking $d$-value index (Murata and Nakata, 1974) can be generally used to define the structural state and the degree of "diagenetic maturity" of opal-CT.

The ratio of opal-CT to diagenetic quartz (based on XRD measurements) serves as a rough measure for the mineralogical maturity of the silicified sediments (Figure 7). Sediments containing high detrital quartz and low opal-CT contents were not used for this ratio. It has to be stressed that two factors can give unrealistic "maturities": (a) the primary percentage of foraminifera in the sediment which can be directly replaced by quartz (Keene, 1975), and (b) high fluctuations of quartz-replaced versus unsilicified foraminifera in and around nodular cherts.

The opal-CT to quartz versus age plot of the Leg 41 samples (Figure 7) shows that only quartz cherts (C II) are present in Late Jurassic to Early Cretaceous (predominantly calcareous) sediments ranging in age from 150 m.y. to about 75 m.y. (about 95 m.y., if samples from Legs 2, 3, and 14 are included). Porcellanites and quartz cherts are present in Late Cretaceous to Eocene carbonate rocks (BII, CII, and transitions) but only porcellanites are present during this time in the clayey environment (BI 1-3). Only porcellanites occur in post-Eocene rocks.

This strongly suggests that maturation with time and temperature is the major driving force for the 


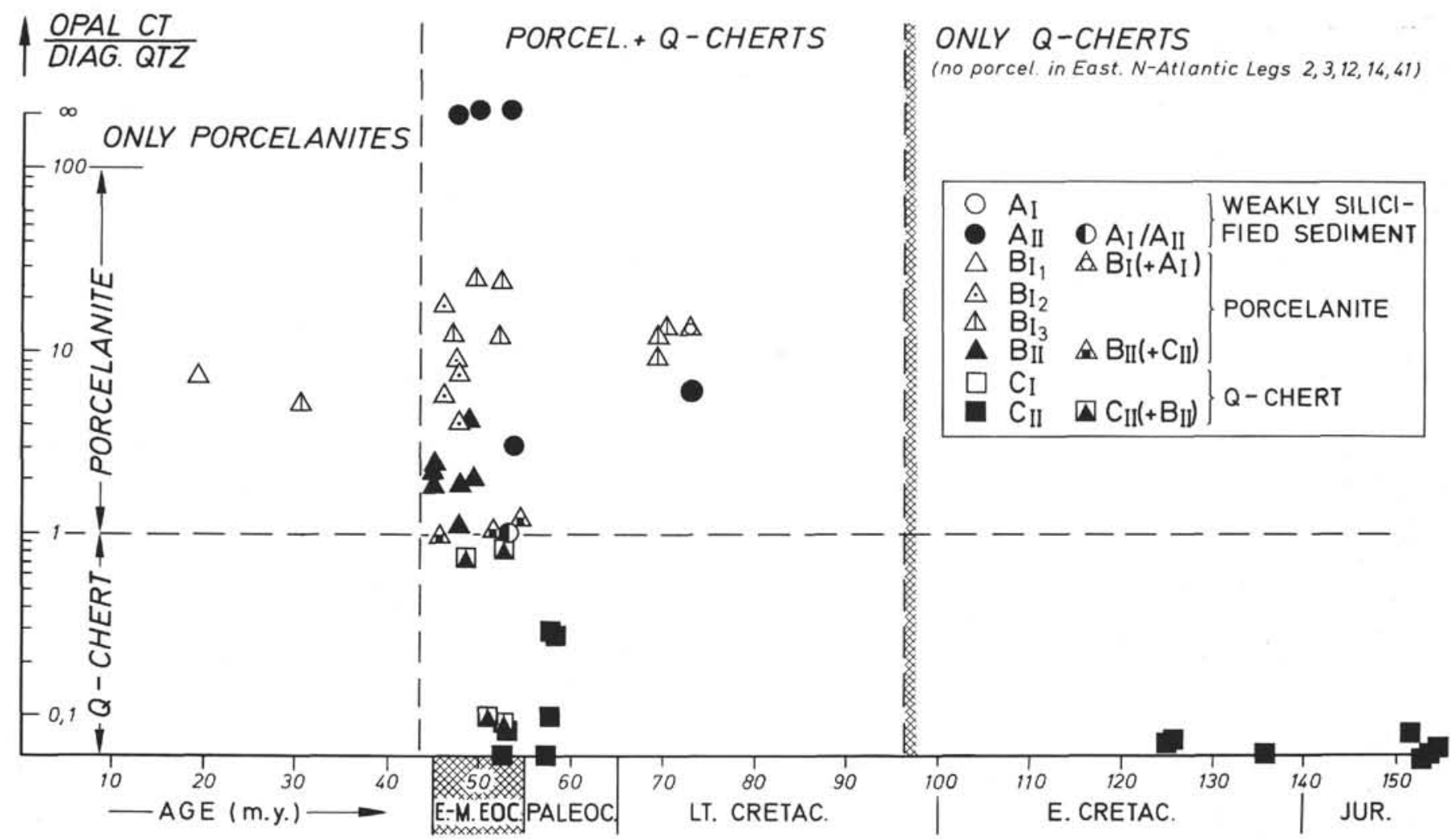

Figure 7. Opal-CT to quartz ratio plotted versus sample age (for symbols see Table 1).

chertification in the clayey and carbonate environments. Geochemical factors such as the host rock lithology and the concentration of silica in the pore solutions exert an important influence on the rate of that transformation process.

\section{REFERENCES}

Aubry, M.-P., 1975. Recherches sur la nannopetrographie des roches silicieuses: Bull. Trim. Soc. Géol. Normandié et Amis Muséum du Havre, Tome LXII, fasc. 2-2e trim., p. 7-34.

Berger, W.H. and von Rad, U., 1972. Cretaceous and Cenozoic sediments from the Atlantic Ocean. In Hayes, D.E., Pimm, A.C., et al., Initial Reports of the Deep Sea Drilling Project, Volume 14: Washington (U.S. Government Printing Office), p. 787-954.

Bromley, R.G., Schulz, M.-G., and Peake, N.B., 1975. Paramoudras: Giant flints, long burrows and the early diagenesis of chalks: Det kongelige Danske Videnskabernes Selskab, Biol. Skrifter, v. 20, p. 1-31.

Calvert, S.E., 1971. Composition and origin of North Atlantic deep sea cherts: Contrib. Mineral. Petrol., v. 33, p. 273-288.

1974. Deposition and diagenesis of silica in marine sediments. In Hsü, K.J. and Jenkyns, H.C. (Eds.), Pelagic sediments: on land and under the sea: Spec. Publ. 1, Intl. Assoc. Sedimentol., p. 273-299.

Chapman, S.L., Syers, J.K., and Jackson, M.L., 1969. Quantitative determination of quartz in soils, sediments and rocks by pyrosulfate fusion and hydrofluosilicic acid treatment: Soil Sci., v. 107, p. 348-355.

Flörke, O.W., Hollmann, R., von Rad, U., and Rösch, H., 1976. Intergrowth and twinning in opal-CT lepispheres. Contrib. Mineral. Petrol.

Flörke, O.W., Jones, J.B., and Segnit, E.R., 1975. Opal-CT crystals: Neues J. Miner. Mh., v. 8, p. 369-377.
Froehlich, F., 1974. Nature, importance relative et place dans la diagenèse des phases de silice présentes dans les silicifications des crais du Bassin océanique de Madagascar (Océan Indien) et du Bassin de Paris: Geol. Soc. France Bull., v. 16, p. 498-508.

Hakansson, E., Bromley, R., and Perch-Nielsen, K., 1974. Maastrichtian chalk of north-west Europe-a pelagic shelf sediment. In Hsü, K.J. and Jenkyns, H.C. (Eds.), Pelagic sediments: on land and under the sea: Spec. Publ. 1, Intl. Assoc. Sedimentol., p. 211-233.

Heath, G.R. and Moberly, R., Jr., 1971. Cherts from the Western Pacific, Leg 7, Deep Sea Drilling Project: In Winterer, E.L., Riedel, W.R., et al., Initial Reports of the Deep Sea Drilling Project, Volume 7: Washington (U.S. Government Printing Office), p. 991-1007.

Henderson, J.H., Clayton, R.N., Jackson, M.L., Syers, J.K., Rex, R.W., Brown, J.L., and Sachs, I.B., 1972. Cristobalite and quartz isolation from soils and sediments by hydrofluosilicic acid treatment and heavy liquid separation: Soil Sci. Soc. Am. Proc., v. 36, p. 830-835.

Jones, J.B. and Segnit, E.R., 1971. The nature of opal, I. Nomenclature and constituent phases: J. Geol. Soc. Australia, v. 18 , p. $57-68$.

Kastner, M. and Keene, J.B., 1975. Diagenesis of pelagic siliceous oozes: Ninth Intl. Congr. Sedimentol., Nice, p. $89-99$.

Keene, J.B., 1975. Cherts and porcellanites from the North Pacific, Deep Sea Drilling Project Leg 32. In Larson, R.L., Moberly, R., et al., Initial Reports of the Deep Sea Drilling Project, Volume 32: Washington (U.S. Government Printing Office), p. 429-507.

Lancelot, Y., 1973. Chert and silica diagenesis in sediments from the Central Pacific. In Winterer, E.L., Ewing, J.I., et al., Initial Reports of the Deep Sea Drilling Project, Volume 17: Washington (U.S. Government Printing Office), p. 377-506. 
SILICA DIAGENESIS IN CONTINENTAL MARGIN SEDIMENTS OFF NORTHWEST AFRICA

Leclaire, L., 1974. Late Cretaceous and Cenozoic pelagic deposits-paleoenvironment and paleooceanography of the central western Indian Ocean. In Simpson, E.S.W., Schlich, R., et al., Initial Reports of the Deep Sea Drilling Project, Volume 25: Washington (U.S. Government Printing Office), p. 481-513.

Millot, G., 1970. Geology of clays: New York, Heidelberg, Berlin (Meson and Gie, Chapman and Hall).

Murata, K.J. and Larson, R.R., 1975. Diagenesis of Miocene siliceous shakes, Temblor Range, California: J. Res. U.S. Geol. Surv., v. 3, p. 553-566.

Murata, K.J. and Nakata, J.K., 1974. Cristobalitic stage in the diagenesis of diatomaceous shale: Science, v. 18, p. 567.

Oehler, J.H., 1973. Tridymite-like crystals in cristobalitic "cherts": Nature Phys. Sci., v. 241, p. 64-65.

vo Rad, U. and Rösch, H., 1972. Mineralogy and origin of clay minerals, silica and authigenic silicates in Leg 14 sediments. In Hayes, D.E., Rim, A.C., et al., Initial Reports of the Deep Sea Drilling Project, Volume 14: Washington (U.S. Government Printing Office), p. 727751.
1974. Petrography and diagenesis of deep-sea charts from the Central Atlantic. In Hs, K.J. and Jenkyns, H.C. (Eds.), Pelagic sediments: on land and under the sea: Spec. Publ. 1, Intr. Assoc. Sedimentol., p. 327-347.

Weaver, F.M. and Wise, S.W., Jr., 1972. Ultramorphology of deep sea cristobalitic chert: Nature Phys. Sci., v. 237, p. 56-57.

Wise, S.W., Jr. and Welts, K.R., 1972. Inferred diagenetic history of weak silicified deep sea chalk: Gulf Coast Assoc. Geol. Soc. Trans., v. 22, p. 172-203.

Wise, S.W., Jr. and Weaver, F.M., 1973. Origin of cristobalite-rich Tertiary sediments in the Atlantic and Gulf Coastal Plain: Gulf Coast Assoc. Geol Soc. Trans., v. 23 , p. $305-323$.

, 1974. Chertification of oceanic sediments. In Hs, K.J. and Jenkyns, H.C. (Eds.), Pelagic sediments: on land and under the sea: Spec. Publ. 1, Inti. Assoc. Sedimentol., p. 301-326.

Wise, S.W., Jr., Brie, B.F., and Weaver, F.M., 1972. Chemically precipitated sedimentary cristobalite and the origin of chert: Eclog. Geol. Helve., v. 65, p. 157-163.

897 


\section{PLATE 1}

Thin-section and SEM photomicrographs of bedded porcellanites $(\mathrm{BI})$

Figure 1 Sample 368-36-3, 47-49 cm (Late Cretaceous to early Eocene; thin-section photo 37/29). Silicified sepiolite-palygorskite mudstone (AI/BI3: see Table 1) with "aggregate polarization." Matrix in light-colored areas shows uniform extinction parallel to the laminations and maximum brightness in the $45^{\circ}$ position.

Figure 2 Thin section photo 37/23 of Sample 368-36-3, 47$49 \mathrm{~cm}$. Opal-CT filled "winged" radiolarian in a matrix with mass polarization. Maximum brightness is observed under $0^{\circ}$ position and crossed nicols in those areas where the lamination is inclined $45^{\circ}$ to the horizontal. This is frequent around microfossils because of differential compaction.

Figure 3 Sample 367-10-1, 126-128 cm (middle Eocene, SEM $542 / 10,4000 \times$ ). Authigenic palygorskite fibers filling a void in a bedded porcellanite. The matrix consists mainly of dense opal-CT (with a few hexagonal blades on the surface).

Figure 4 Sample 367-14-4, 14-16 cm (early Eocene, SEM $727 / 3,3000 \times$ ). Bedded porcellanite with early diagenetic palygorskite mats oriented \pm parallel to elongated void. Radiolarian ghosts are filled only by lepispheres and clinoptilolite.

Figure 5 Sample 367-14-4, 14-16 cm (SEM 726/10, 3000×). Radiolarian ghost filled by well-bladed authigenic lepispheres $(5-8 \mu \mathrm{m})$ and euhedral clinoptilolite crystals (probably latest void filling mineral).

Figure 6 Sample 367-10-1, 126-128 cm (SEM 555/9, $6400 \times$ ). Massive, structureless, opal-CT matrix (inhibited growth) in bedded porcellanite. Minute platy crystallites and spherulitic masses of opalCT line open void as free-growth front. 
PLATE 1
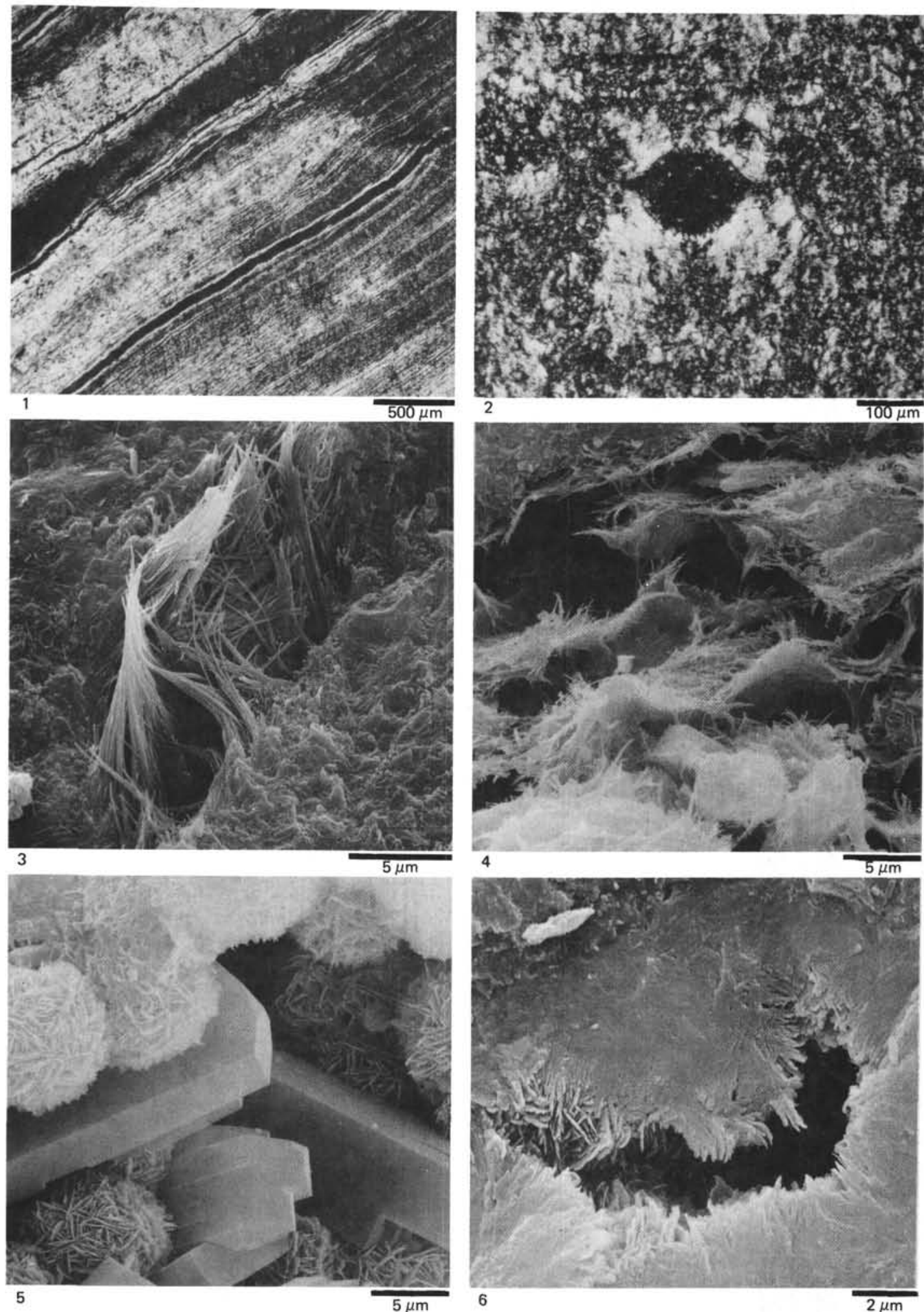


\section{PLATE 2}

Ultrastructure of lepispheres; nodular porcellanites, silica-cemented conglomerate

Figure 1 Sample 366-23-1, 39-41 cm (TEM 19863). Transmission electron photo of lepisphere aggregates.

Figure 2 Sample 366-23-1, 39-41 cm (TEM 19869). Electron diffraction pattern of material from an isolated lepisphere. The innermost rim corresponds to the opal-CT strongest reflection at $d=4.1 \AA$.

Figure 3 Sample 366-31-4, 91-93 cm (early Eocene, 34/21). Foraminifer with calcitic test in a carbonate matrix (AII), partially replaced by opal-CT. The lower part of the filling of the microfossil consists of dense opal-CT replacing a geopetal micritic sediment fill with relict coccoliths. The upper rim of the dense opal-CT is made up by lepispheres (first cement), and the remaining pore space filled by (clear) quartz cement (second silica cement).

Figure 4 Sample 366-29-1, 50-52 cm (early Eocene, 38/22). Nodular porcellanite (BII) with silicified foraminifera (tests $=$ quartz, filling $=$ opal-CT). The opal-CT filling of the foraminifera is more transparent than the dense matrix opal-CT (more lepispheres in voids).

Figure 5 Sample $370-12-2,32-34 \mathrm{~cm}$ (middle Eocene, 37/34). Opal-CT as cement in a conglomerate: dense matrix and small spherules (lower left) replacing porous micrite between pebbles (relict nannofossils) is overgrown by large opal-CT hemispheres toward the open cavity. Remaining pore space unfilled.

Figure 6 Sample $370-12-2,32-34 \mathrm{~cm}(37 / 35, \times$ nicols $)$. Same feature as in Figure 5, but the opal-CT rim cement is replaced by chalcedonic quartz. The remaining \pm isotropic matrix is still preserved as opal-CT (upper left).

Figure 7 Sample 370-15-2, 139-141 cm (middle Eocene, $38 / 14$, $\times$ nicols). Sharp boundary between microcrystalline quartz chert (left) and porcellanitic precursor sediment (right) along quartz-filled vein, probably formed between the porcellanite and chert stage. The porcellanite already contains many quartz nuclei.

Figure 8 Sample 370-15-1, 42-44 cm (middle Eocene, 38/10, $\times$ nicols). Laminated quartz chert in marlstone with bedded relict porcellanite cut at a vein-like structure (right-hand). 
PLATE 2
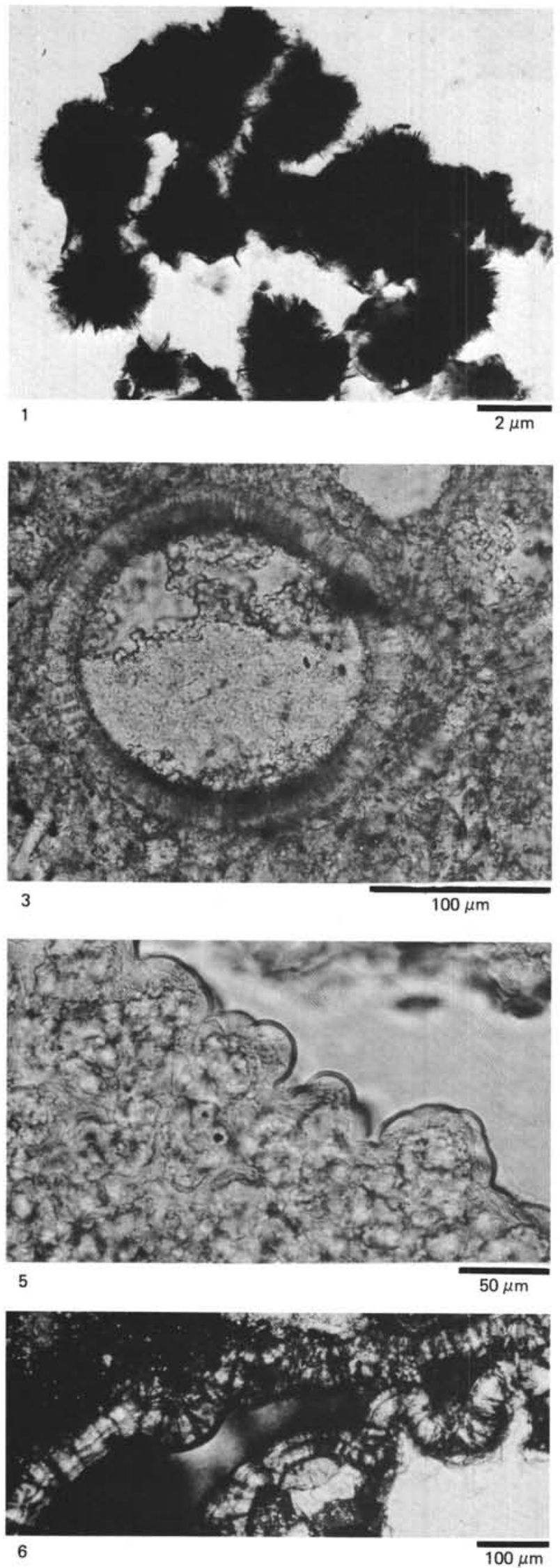
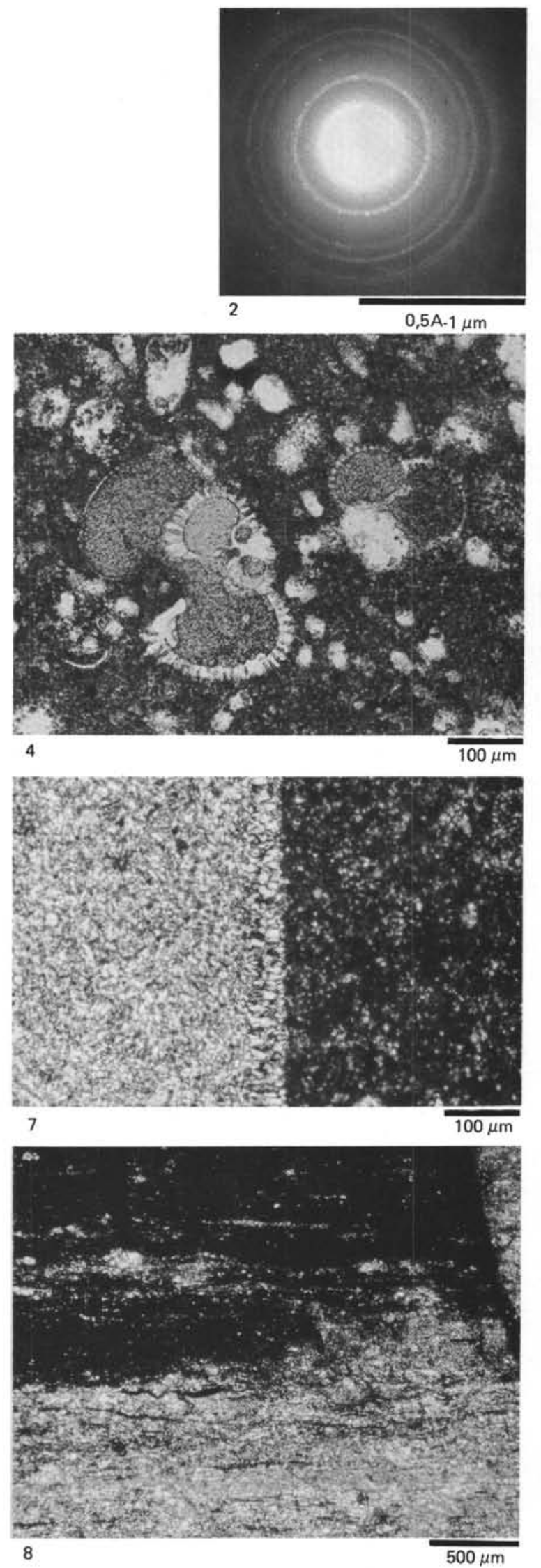


\section{PLATE 3}

Preservation and filling of radiolarians and foraminifera

Figure 1 Sample 367-31-1, 64-66 cm (Berriasian, 729/5, $225 \times, \mathrm{HCl}$ residue of limestone). Broken-up, quartz replaced radiolarian with quartz-replaced lepispheres.

Figure 2 Detail of Figure $1(729 / 6,900 \times)$. Note that gross morphology of lepisphere is preserved after replacement by quartz; the detailed morphology (blades and interpenetration "twins," see Figure 5) has been destroyed.

Figure 3 Detail of Figure $2(729 / 7,4500 \times)$. Surface of quartz-replaced lepisphere.

Figure 4 Sample 369A-35-1, 104-106 cm (middle Eocene, $630 / 8,400 \times$ ). Foraminifer in an $\mathrm{HCl}$-treated porcellanite. The calcitic test is dissolved so only the opal-CT filling of the pores of the chamber walls and the interior of the chambers is left.

Figure 5 Sample 369A-35-1, 104-106 cm (540/2, 7200X; not acid-treated). The inner wall of a foraminiferal chamber in weakly silicified chalk (AII) is covered by early-diagenetic calcitic cement $A$, on top of which opal-CT is crystallized as: embryonic lepisphere (few isolated and interpenetrated opalCT blades, upper left) and (later) fully-developed, complete lepispheres with typical interpenetration structure at distinct angles (see Figure 5b).

Figure 6 Sample 366-29-1, 59-61 cm (early Eocene, 625/3, $2000 \times$ ). Weakly silicified zone (AII) of porcellanite nodule. Lepispheres along inner wall of calcitic foraminiferal test (upper right), overgrown by late-diagenetic calcite cement B. A negative (mold) of lepisphere in calcite crystal is seen at the lower right. 
PLATE 3
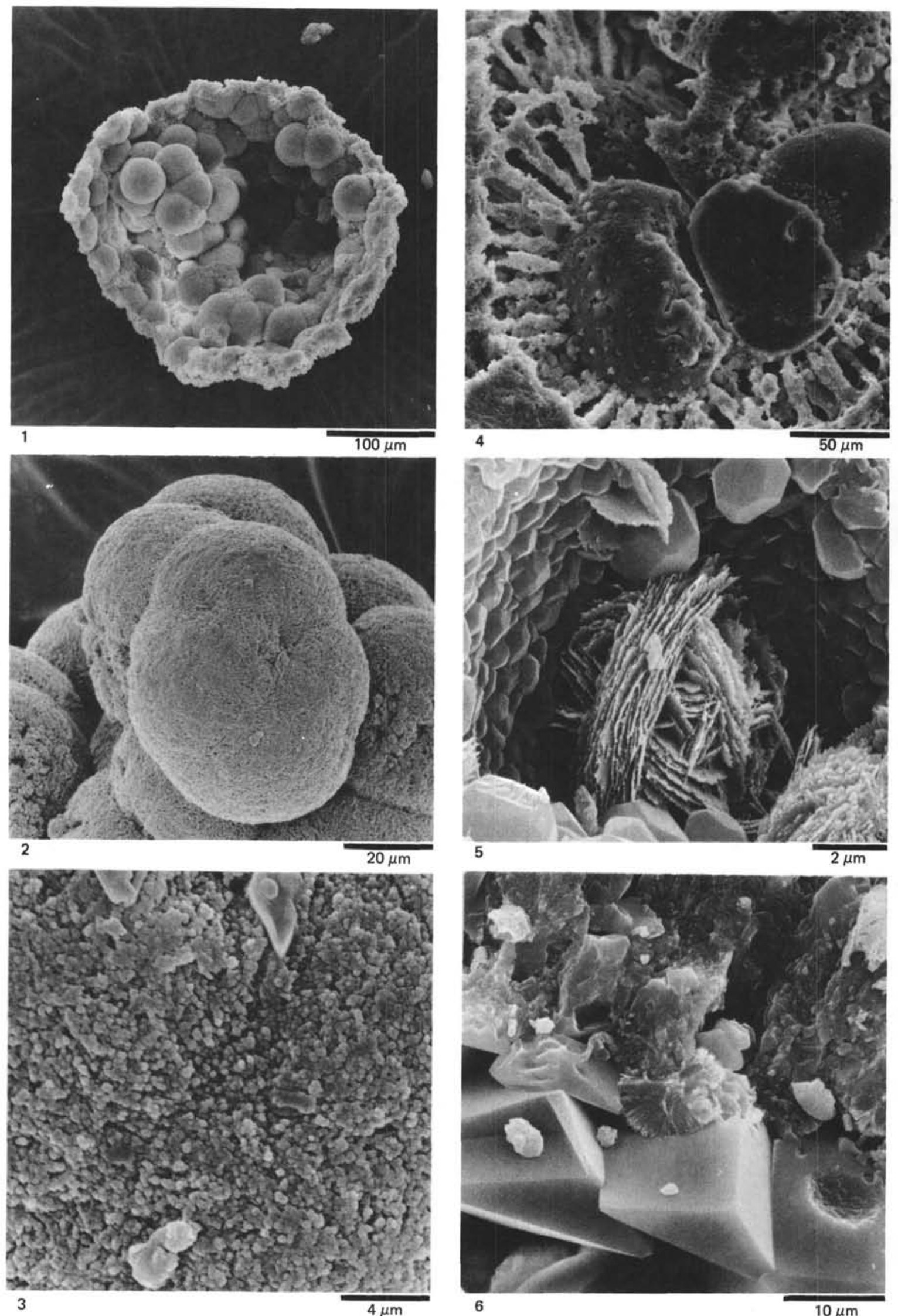


\section{PLATE 4}

Opal-CT and quartz-replaced radiolarians and opal-CT molds

Figure 1 Sample 366-23-1, 42-44 cm (middle Eocene, 643/7, $300 \times$, HCl-residue of a limestone). Opal-CT replaced, well-preserved skeleton of a radiolarian.

Figure 2 Detail of Figure 1 (inner sphere, 632/10, 600×). Lepispheres formed on the outer surface.

Figure 3 Detail of Figure $2(644 / 5,6000 \times)$. Opal-CT blades and lepispheres on the surface of the central capsule. The opal-CT of the skeleton has included coccoliths (negative seen at upper left) by active outward growth.

Figure 4 Sample 370-12-2, $55-57 \mathrm{~cm}$ (middle Eocene, $638 / 11,260 \times)$. Well-preserved, quartz-replaced radiolarian skeleton $\left(\mathrm{H}_{2} \mathrm{SiF}_{6}\right.$-residue from claystone pebble from conglomerate).

Figure $5 \quad$ Detail of Figure $4(638 / 10,2000 \times)$. Granular surface of quartz-replaced skeleton.

Figure 6 Sample 366-23-1, 42-44 cm (middle Eocene, $645 / 480 \times$, HCl-residue of a weakly silicified chalk, AII). Foraminiferal chamber filled by dense opal-CT and lepispheres. 
PLATE 4
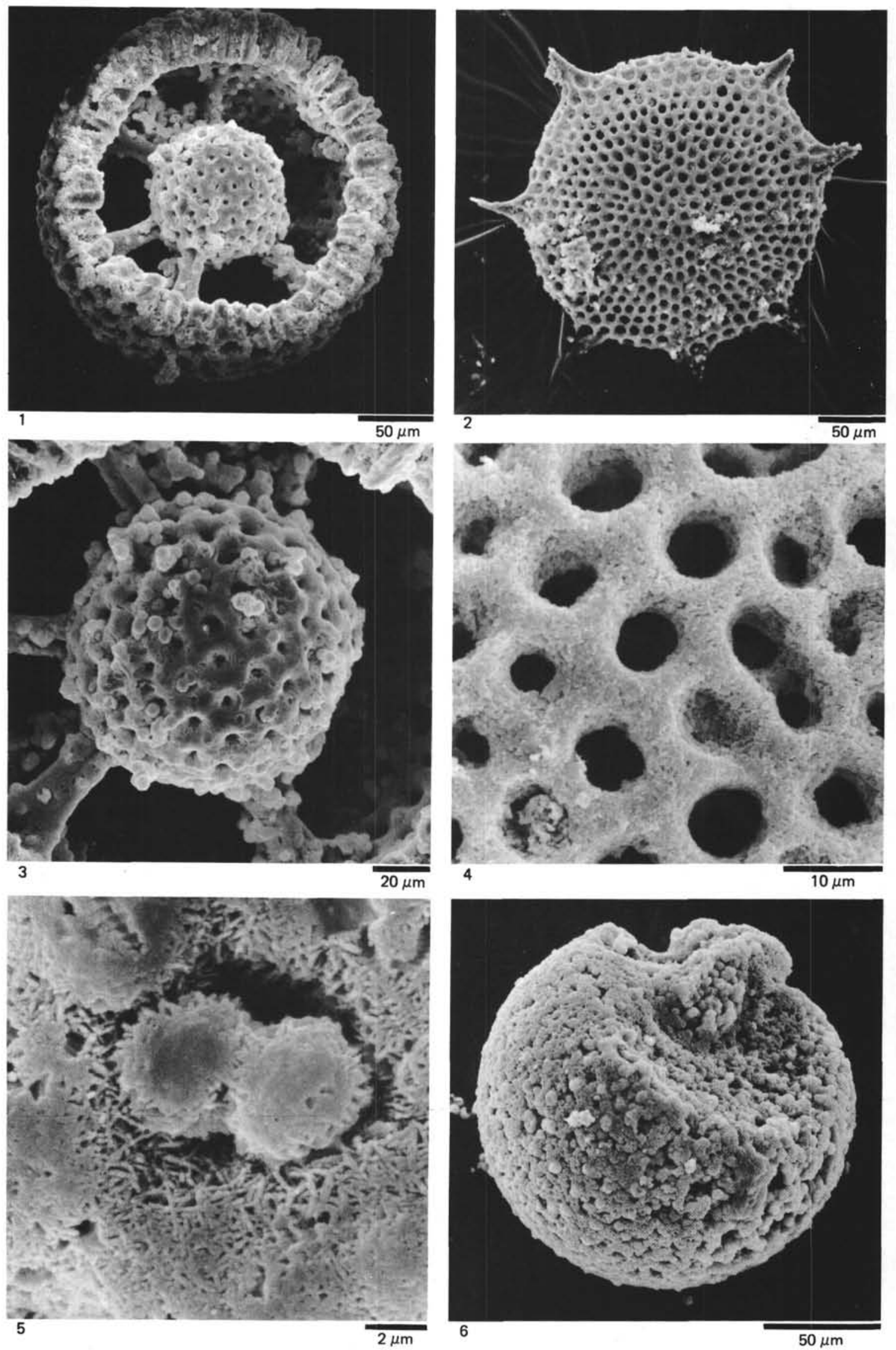